\title{
DV Vauvaperheiden vanhempien kokemat huolet ja muutokset sosiaalisissa suhteissa ja jaksamisessa koronaepidemian aikana
}

Koronaepidemia on muuttanut perheiden arkea. Epidemian alussa ei ollut tietoa viruksen tarttuvuudesta raskaana olevaan tai sen vaarallisuudesta raskaana olevalle, sikiölle ja vastasyntyneelle. Tutkimuksen tarkoituksena on selvittää koronaepidemiaan liittyviä huolia ja vanhempien sosiaalisissa suhteissa ja jaksamissa koettuja muutoksia.

Aineistona oli 3-6 kuukauden ikäisten vauvojen vanhemmille suunnatun FinLapset-kyselytutkimuksen syksyn 2020 otoksiin vastanneet (äidit, $N=4550$; isät, $N=2955$ ). Tuloksia tarkasteltiin vanhemman sukupuolen, koulutuksen ja iän, perheen lapsiluvun ja taloudellisen tilanteen mukaan. Logistisessa regressioanalyysissa yhden lapsen vanhempia verrattiin useamman lapsen vanhempiïn vakioiden vanhemman ikä, koulutus ja perheen taloudellinen tilanne.

Äitien vastausaktiivisuus oli $50 \%$ ja isien $36 \%$. Useampi äideistä, erityisesti yhden lapsen äideistä, kuin isistä kertoi koronaepidemiaan liittyvistä huolista. Yleisimmät huolet olivat synnytys ja synnytyssairaalassa olo korona-aikana. Iso osa vanhemmista ei kokenut koronaepidemian vaikuttaneen sosiaalisiin suhteisiin tai jaksamiseen. Äideillä jaksaminen polarisoitui: osa koki jaksamisen vähentyneen $(25 \%)$ ja osa lisääntyneen (16\%). Lähes puolet vanhemmista koki perheen yhteisen ajan lisääntyneen ja $13 \%$ äideistä ja $5 \%$ isistä vähentyneen. Vanhemmista huomattavasti useampi koki yhteydenpidon ystäviin ja isovanhempiin vähentyneen kuin lisääntyneen. Yksinäisyyden tunteen koki lisääntyneen selvästi useampi äiti (48\%) kuin isä (21 \%). Jaksamisen polarisoitumisesta ja sosiaalisten suhteiden vähentymisestä raportoi isompi osa useamman kuin yhden lapsen vanhemmista ja perheen yhteisen ajan vähentymisestä isompi osa yhden kuin useamman lapsen vanhemmista.

Koronaepidemialla on kielteisiksi ja myönteisiksi koettuja vaikutuksia vauvaperheiden hyvinvointiin. Sekä isien että äitien jaksamiseen ja heille tarjottuun tukeen ja palveluihin tulee kïnnittää huomiota ja seurata pikkulapsiperheiden terveyttä ja hyvinvointia myös tulevaisuudessa.

ASIASANAT: hyvinvointi, koronaepidemia, vauva, vanhempi

REIJA KLEMETTI, MAARET VUORENMAA, EETU ERVASTI, SATU HELAKORPI, JOHANNA LAMMI-TASKULA 


\section{YDINASIAT}

- Tieto vauvaperheiden hyvinvoinnista koronaepidemian aikana on vähäistä.

- Koronaepidemia huolestutti erityisesti yhden lapsen perheitä ja perheen kanssa vietetty aika oli etenkin heidän mielestään vähentynyt.

- Kokemus yksinäisyyden tunteen lisääntymisestä oli yhteinen, mutta koski erityisesti äitejä.

- Jaksaminen arjessa polarisoitui useamman lapsen äideillä.

- Vauvaperheiden vanhempien jaksamisen tukemiseen on syytä kiinnittää huomiota ja selvittää epidemian mahdollisia pitkänajan vaikutuksia.

\section{JOHDANTO}

COVID-19- eli koronaepidemia on aiheuttanut huomattavia muutoksia suomalaisten lapsiperheiden elämään ja heille tarjottaviin palveluihin. Koronaepidemian aikana lasten ja heidän vanhempiensa hyvinvoinnissa on tapahtunut sekä myönteistä että kielteistä kehitystä. Monissa perheissä on koettu kuormittuneisuuden, huolten ja epävarmuuden lisääntyneen, kun taas osalle poikkeusolot ovat merkinneet perheen lisääntynyttä yhteistä aikaa ja kiireen vähenemistä arjessa. (1-4.)

Vanhemmuus tuo mukanaan monia muutoksia elämään. Koronavuonna näihin muutoksiin on yhdistynyt pandemian vaikutus (5). Lapsen saaminen vaikuttaa muun muassa työssäkäyntiin, tuloihin, terveyteen, vapaa-aikaan ja parisuhteeseen. Ennen ensimmäistä lasta tulevilla vanhemmilla ei ole suoraa käytännön kokemusta vanhemmuudesta. Toisen lapsen kohdalla vanhemmilla on jo tietoa ja kokemus lapsiperhearjesta. Myrskylä ja Margolis (6) havaitsivat, että vanhempien onnellisuus lisääntyy eniten ensimmäisen lapsen saamisen myötä ja jonkin verran toisen lapsen myötä, mutta vähenee kolmannen lapsen jälkeen.

Keskeisiä haasteita esikoislapsen saaneilla vanhemmilla ovat yksilöllisen ja parisuhteen identiteetin muutos, työnjako vanhempien kesken lapsen hoidossa ja kotitöissä sekä sosiaaliset normit ja odotukset hyvästä vanhemmuudesta (7). Erityisesti synnyttäneitä äitejä kuormittavat väsymys, huolet ja vanhemmuuden vastuu sekä työmäärä (8).
Lapsiperheiden vanhempien kokemus hyvinvoinnista on vahvasti yhteydessä perheen toimeentuloon, mutta merkitystä on myös sosiaalisilla verkostoilla, terveydentilalla, palvelujen ja etuuksien saatavuudella, talouden odottamattomilla käänteillä sekä työn ja perhe-elämän yhteensovittamisen arkisella sujuvuudella (9). Lapsiperheiden vanhemmilla, erityisesti äideillä oli jo ennen koronaepidemiaa ollut monenlaisia lapsen kasvuun ja kehitykseen, perheen talouteen, omaan jaksamiseen sekä parisuhteeseen liittyviä huolia $(10,11)$.

Koronapandemian monet terveydelliset ja yhteiskunnalliset vaikutukset tuottavat väestölle ja siten myös lapsiperheiden vanhemmille kasvavaa psyykkistä kuormitusta. Tämä heijastuu niin parisuhteeseen kuin vanhemmuuteenkin ja voi vaikuttaa kielteisesti lasten kehitykseen erityisesti niissä perheissä, joissa on ollut enemmän haavoittuvuutta jo ennen pandemiaa. (5.)

Suomessa kevään 2020 poikkeustilanteessa työttömyys ja lomautukset kohdentuivat perheisiin yksinasuvia voimakkaammin, ja toimeentulohuolet kuormittivat erityisesti ennestään pienituloisia kuten yksinhuoltajia ja monilapsisia perheitä $(12,13)$. Työn ja perheen yhteensovittamisen pulmat korostuivat erityisesti pienten lasten perheissä, kun monet vanhemmat siirtyivät etätyöhön ja samaan aikaan lapset siirtyivät tilapäisesti varhaiskasvatuksesta kotihoitoon $(3,14,16)$. Ansiotyön ja perhe-elämän välinen raja hämärtyi etätyön myötä ja isät olivat periaatteessa enemmän fyysisesti läsnä (17). Silti lastenhoito jäi enemmän äitien harteille (16).

Sosiaalisen etäisyyden suosituksen myötä isovanhempien apu lastenhoidossa jäi vähemmälle ja myös palvelujen saatavuus heikkeni. Osa lapsiperheiden palveluista oli poikkeusolojen aikana auki tai saatavilla rajoitetusti, mikä tuotti katkoksia kasvokkaisiin ja luottamuksellisiin asiakassuhteisiin ja muodosti osaltaan riskin lasten, nuorten ja perheiden hyvinvoinnille. $(2,17,19$.)

Salin ja muut (16) tulkitsivat lapsiperheille suunnatun kyselynsä tulosten perustella, että perheiden selviytymiskeinot koronakevään aikana liittyivät yhtäältä yhteiskunnan palveluista saatavaan tukeen ja työelämän joustoihin, toisaalta perhesuhteisiin, perheenjäsenten keskusteluyhteyteen ja perheen arjen joustaviin käytäntöihin sekä kolmantena yksilöllisiin asenteisiin ja jousta- 
vuuteen. Näistä ulottuvuuksista keskeisimmäksi nousivat perhesuhteet, jotka toimivat laajempien yhteiskunnallisten rakenteiden kuin yksilöllistenkin asenteiden välittäjinä ja suodattajina. Yhden lapsen perheessä perhesuhteet rakentuvatkin parisuhteen ohella vanhempien ja lapsen välisistä dyadisista eli kahdenvälisistä suhteista (20). Useamman lapsen perheessä dyadisten suhteiden määrän lisääntymisen vuoksi perhe-elämän ihmissuhteet muodostuvat vielä monimutkaisemmiksi kuin yksilapsisessa perheessä.

Raskaana olevien ja synnyttävien perheiden näkökulmasta epidemiaan liittyy erityisiä huolenaiheita. Näyttäisi siltä, että riski saada vakava koronavirustauti on suurempi niillä raskaana olevilla, joilla on jokin vaikealle koronavirustaudille altistava riskitekijä kuten huomattava ylipaino, korkeampi ikä, astma ja verenpaineongelmia $(21,22)$. Myös raskaana olevat ja synnyttäneet äidit voivat sairastaa taudin oireettomana (23), ja onneksi tauti on raskaana olevilla usein lievä $(22,24,26)$. Toisaalta raskaana olevilla on koronavirustaudin yhteydessä todettu muita useammin laskimotukos (22,27-29), ja he ovat tarvinneet teho- ja hengityskonehoitoa hieman muita saman ikäisiä naisia useammin $(22,28,30)$.

Koronaepidemian aikana joissakin synnytyssairaaloissa jouduttiin supistamaan palveluja, jotta voitiin taata riittävä henkilökunnan määrä. Lähes kaikissa sairaaloissa pystyttiin kuitenkin säilyttämään ennallaan synnytystoimintaan liittyvät palvelut. Keväällä 2020 huolestuttiin perheiden nopeasta kotiuttamisesta synnytyksen jälkeen. Hoitoilmoitusrekisterin ennakkotietojen perusteella hoitoajat lyhenivät kuitenkin pääosin vain maaliskuussa 2020. (19.)

Synnyttäjien ja vastasyntyneiden riskistä vakavaan koronavirustautiin ei epidemian alussa ollut tutkittua tietoa. Synnyttämään valmistautuva perhe jäi siis useissa kunnissa ilman tarvitsemaansa tukea neuvolapalvelujen (18) ja sairaalan tarjoamien synnyttäjille suunnattujen palvelujen supistuessa ja muuttaessa muotoaan (19).

Synnytyssairaaloissa toteutetut tukihenkilörajoitukset aiheuttivat odottaville perheille huolta $(31,32)$. Tukihenkilörajoitusten luoma stressi, pelko ja tuen puute vaikuttivat synnyttäjien henkiseen hyvinvointiin ja jaksamiseen. Tukihenkilöllä, joka pääsääntöisesti on syntyvän lapsen isä, on tärkeä merkitys synnytyksen säännölliselle kululle ja synnyttäjän psyykkiselle hyvinvoinnille erityisesti koronaepidemian aikana $(25,32)$. Isän läsnäolo on koko perheen hyvinvoinnin kannalta tärkeää, sillä se mahdollistaa kiintymyssuhteen syntymisen isän ja vastasyntyneen välille ensi hetkistä alkaen $(32,33)$.

Koronaepidemian vaikutuksista lapsiperheiden arkeen tiedetään siis jo jonkin verran, mutta osa tiedosta perustuu erilaisiin selvityksiin, ennakkotietoihin tai pienehköihin aineistoihin. Tämän tutkimuksen tarkoituksena on selvittää koronaepidemiaan liittyviä vauvaperheen vanhempien huolia ja heidän omaa arviotaan jaksamisensa ja sosiaalisten suhteidensa muuttumisesta epidemian aikana käyttäen laajaa kansallista aineistoa. Koska monet tilanteet, kokemukset ja perhe-elämä kokonaisuudessaan ovat erilaisia ensimmäisen ja useamman lapsen perheissä, äitien ja isien huolia, jaksamista ja sosiaalisia suhteita tutkitaan erikseen suhteessa perheen lapsilukuun (yksi lapsi vs. useita lapsia perheessä).

\section{MENETELMÄT}

\section{AINEISTO}

FinLapset-kyselytutkimus 3-6-kuukauden ikäisten vauvojen perheille käynnistyi maaliskuussa 2020. Kyselytutkimuksen tavoitteena oli selvittää vauvaperheiden terveyttä, hyvinvointia ja kokemuksia palveluista ja niiden riittävyydestä. Tutkimusta varten Digi- ja väestötietoviraston (DVV) väestötietojärjestelmästä poimittiin kuusi otosta eli tiettyinä aikoina syntyneiden lasten vanhempien tiedot: osoite, ikä, sukupuoli, siviilisääty, syntymämaa ja asiointikieli. Osoitetietoa käytettiin vain vanhempien tavoittamiseen. Syntymämaan perusteella tehtiin muuttuja ulkomaalaistaustainen/muu.

Kyselyyn vastasi yhteensä 14820 vanhempaa. Tämän tutkimuksen aineistona ovat syksyn 2020 kolme otosta, joissa tutkimukseen kutsuttiin yhteensä 17489 vanhempaa ja joissa vanhempien kyselylomakkeeseen lisättiin kysymyksiä koronaepidemian aiheuttamista huolista ja epidemian vaikutuksista perheen arkeen. Näissä otoksissa vauvat olivat syntyneet aikavälillä 20.4.-12.7. 2020 ja vanhemmat vastasivat elokuun 2020 ja tammikuun 2021 välisenä aikana. Vastaajia oli yhteensä 7517. Tässä tutkimuksessa keskitytään äitien ja isien vastauksiin, joten aineistosta jätettiin pois 12 naispuolista toista vanhempaa. Tä- 
män tutkimuksen aineiston vastaajia on siis yhteensä 7505 .

Vanhempia lähestyttiin tarvittaessa neljä kertaa. Ensimmäisellä kerralla he saivat kutsukirjeen, jossa oli tunnukset sähköiseen vastaamiseen Terveyden ja hyvinvoinnin laitoksen (THL) sähköisen lomakepalvelun kautta ja arvontakortti. Ensimmäinen muistutus tutkimukseen osallistumisesta lähetettiin reilun kahden viikon kuluttua kutsusta. Muistutus sisälsi paperisen lomakkeen ja tietosuojailmoituksen. Toinen muistutus oli muistutuskortti, joka postitettiin neljä ja puoli viikkoa ensimmäisestä muistutuksesta. Kolmas muistutus lähetettiin kolme viikkoa toisen jälkeen, ja silloin vanhemmat saivat jälleen paperisen kyselylomakkeen.

Vanhemmilla oli mahdollisuus valita seitsemästä kielestä: suomi, ruotsi, englanti, venäjä, arabia, somali ja pohjoissaame. Lähestyminen tehtiin sen kielen perusteella, joka oli DVV:llä merkitty asiointikieleksi. Jos asiointikieltä ei ollut, lähestymiskieli valittiin äidinkielen perusteella. Jos kieli oli joku muu kuin tutkimukseen valitut kielet, lähestyttiin englanninkielisellä kutsulla.

Tutkimus sai THL:n tutkimuseettisestä toimikunnasta puoltavan lausunnon 10.2.2019 (THL/1535/6.02.01/2019), ja 9.6.2020 toimikunta hyväksyi koronakysymysten lisäämisen kyselylomakkeeseen.

\section{MITTARIT}

Koronaepidemiaan liittyviä huolia tutkittiin yhdellä kysymyksellä, jossa lueteltiin kuusi huolenaihetta. Kysymys pohjautui THL:n muotoilemiin huolikysymyksiin, jotka perustuivat WHO:n Euroopan toimiston ja Erfurtin yliopiston kehittämään Behavioural Insights on COVID-19 -työkaluun (32). Huolenaiheita muokattiin vauvaperheiden elämäntilanteeseen sopiviksi kysymällä Oletko ollut huolissasi 1) koronavirustartunnan saamisesta, 2) muiden tartuttamisesta, 3) vauvan odotusajan sujumisesta koronaepidemian aikana, 4) synnytyksen sujumisesta koronaepidemian aikana, 5) synnytyssairaalassa oloajasta koronaepidemian aikana ja 6) koronaviruksen vaarallisuudesta sikiölle tai vauvalle? Vastausvaihtoehtoina olivat: en ollenkaan, vähän, kohtalaisesti, melko paljon, hyvin paljon. Analyyseja varten melko paljon ja hyvin paljon huolissaan olevat yhdistettiin yhdeksi luokaksi ("melko tai paljon huolissaan olevat").
Vauvaperheiden kokemuksia koronaepidemian tai siihen liittyvien rajoittamistoimien vaikutuksista sosiaalisiin suhteisiin (3 teemaa), vanhempien jaksamiseen (1 teema), parisuhteeseen ja perheen yhteiseen aikaan ( 3 teema) kysyttiin kysymyksellä: Ovatko koronaepidemia tai sen rajoittamistoimet vaikuttaneet arkielämääsi? Vastausvaihtoehtoina olivat: ei vaikutusta; kyllä, vähentynyt; kyllä, lisääntynyt ja ei koske minua. Vastaukset jaettiin kolmeen luokkaan: ei vaikutusta, vähentynyt ja lisääntynyt. Vaihtoehto 'ei koske minua' jätettiin analyyseistä pois.

Sosiaalisten suhteiden teemoja olivat: 1) yhteydenpito isovanhempiin, 2) yhteydenpito ystäviin ja 3) yksinäisyyden tunne. Jaksamisen teemana oli jaksaminen arjessa. Parisuhdetta ja perheen yhteistä aikaa koskevia teemoja olivat: 1) puolisoiden välinen läheisyyden tunne, 2) puolisoiden väliset erimielisyydet ja ristiriidat, 3) perheen kanssa vietetyn ajan määrä. Mittarit pohjautuvat THL:lla kehitettyyn kysymyspatteriin, koska kansainvälistä, testattua mittaria ei ollut käytettävissä. Tätä tutkimusta varten jätettiin osa teemoista pois (kuten painajaisunet ja päivittäinen liikunta) ja lisättiin kysymykseen nimenomaan vauvaperheille sopivaksi katsottuja teemoja (kuten yhteydenpito isovanhempiin, oma jaksaminen ja puolisoiden välinen läheisyyden tunne).

Kokemuksia koronaepidemian tai sen rajoittamistoimien vaikutuksesta perheen taloudellisessa tilanteessa tutkittiin yhdellä kysymyksellä: Onko koronaepidemia heikentänyt taloudellista tilannettasi/perheesi taloudellista tilannetta? Vastausvaihtoehtoina olivat: erittäin paljon, melko paljon, jonkin verran, vähän ja ei lainkaan. Jonkin verran, melko paljon ja erittäin paljon vastanneet raportoitiin yhtenä luokkana.

Etätöihin ja -opiskeluun siirtymistä (vain isille ja toiselle vanhemmalle esitetty kysymys) tutkittiin kysymällä: Siirryitkö etätöihin tai -opiskeluun, jos olit työssä tai opiskelemassa ennen koronaepidemiaa? Vastausvaihtoehdot olivat: kyllä, kokonaan; kyllä, osittain ja en. Vastaaja luokiteltiin etätöihin siirtyneeksi, jos hän vastasi siirtyneensä etätyöhön joko kokonaan tai osittain.

Tuloksia tarkasteltiin vanhemmuuden (äiti/ isä), perheen lapsiluvun (ainoa lapsi/useampia lapsia), vanhemman iän (alle 30/30-35/yli 35), koulutuksen (peruskoulu tai vähemmän/vähin- 
tään toisen asteen tutkinto/ammattikorkeakoulutai alempi korkeakoulututkinto/ylempi ammattitai korkeakoulututkinto) ja koetun taloudellisen tilanteen (taloudellinen tilanne kohtalainen tai huono/muut) mukaan. Äideistä 20 ja isistä 21 ei ollut vastannut lapsilukua koskeneeseen kysymykseen, joten lapsiluvun mukaisissa analyyseissä äitejä oli 4530 ja isiä 2934.

\section{KADON ARVIOINTI}

Lakimuutoksesta johtuen lasten huolto -käsittely muuttui väestötietojärjestelmässä ja muutostyö oli DVV:Ilä otosten poimintojen aikana kesken, minkä takia suoramarkkinointikielto ja vanhemman asumisjärjestelyt vaikuttivat poimintaan. Kadon arvioimiseksi verrattiin vastanneita ja vastaamatta jättäneitä vanhempia DVV:n aineiston pohjalta. Sen lisäksi Tilastokeskuksesta pyydettiin samana aikana syntyneiden lasten vanhempien aggregaattitason ikäryhmittäiset koulutusja ammattiasematiedot sukupuolen ja alueen mukaan (35). Koska aineistomme ei sisältänyt vanhempien henkilötunnuksia, Tilastokeskuksen aineistoa ei pyydetty henkilötason tietona eikä sitä voitu yhdistää varsinaiseen tutkimusaineistoon. Vanhempien koulutustiedot ovat vuodelta 2019.

\section{TILASTOLLISET ANALYYSIT}

Tilastollisissa analyyseissä käytettiin jakaumatarkasteluja sekä ristiintaulukointia ja khiin neliötestiä. Khiin neliötestillä verrattiin eroja lapsiluvun mukaan vanhempien taustatekijöissä (Taulukko 1), koronaepidemiaan liittyvissä huolissa (Taulukko 2) sekä koronaepidemian aiheuttamissa arjessa tapahtuneissa muutoksissa (Taulukko 3). Näiden lisäksi koronaepidemiaan liittyviä väittämiä katsottiin vanhempien eri taustatekijöiden mukaan (Liitetaulukko). Tilastollisen merkitsevyyden rajaksi valittiin p-arvo 0,05 .

Koronahuoliin liittyvissä analyyseissä (melko tai paljon huolissaan vs. muut) käytettiin kaksiarvoista logistista regressiota. Arjessa tapahtuneiden muutosten analysointiin käytettiin multinominaalista logistista regressiota, jossa luokka "ei vaikutusta" valittiin viiteluokaksi kahdelle muulle (lisääntynyt/vähentynyt). Vertailuryhmänä olivat useampilapsisten perheiden vanhemmat. Malleissa tulokset esitetään ristitulosuhteina (odds ratio, OR), jotka kuvaavat tapahtuman toteutumisen suhteellista yleisyyttä vertailuryh- mään verrattuna. Ristitulosuhteille esitetään myös $95 \%$ :n luottamusvälit tilastollisen merkitsevyyden sekä mahdollisen vaikutuksen suuruuden tarkastelemiseksi. Malleissa olivat mukana vain päävaikutustekijät. Logistisissa regressioanalyyseissä vakioitiin vanhemman ikä, koulutus ja koettu taloudellinen tilanne (adjusted odds ratio, aOR). Analyyseissä käytettiin RStudioohjelmaa (Versio 4.0.0).

\section{TULOKSET}

\section{VANHEMPIEN TAUSTA JA VASTAUSAKTIIVISUUS}

Syksyn otoksiin kutsutuista kyselyyn vastasi 4550 äitiä (vastausaktiivisuus 50 \%) ja 2955 isää (36\%). Vastaajat olivat tyypillisesti Suomessa syntyneitä, melko korkeasti koulutettuja ja kohtuullisen hyvin toimeentulevia (Taulukko 1). Äitien keski-ikä oli 31,4 (SD 5,1) ja isien 33,7 (SD 5,8) vuotta. Joka kymmenes äiti oli syntynyt muualla kuin Suomessa, isillä osuus oli hieman suurempi $(13,5 \%)$. Vastaajista lähes puolella (46 \%:lla äideistä, $48 \%$ :lla isistä) oli vain yksi lapsi. Yhden lapsen vanhemmat olivat keskimäärin noin kolme vuotta nuorempia kuin vanhemmat, joilla oli useampia lapsia. Reilulla neljäsosalla vastaajista oli ylempi korkeakoulututkinto. Äidit olivat isiä korkeammin koulutettuja, ja yhden lapsen äidit olivat korkeammin koulutettuja kuin useamman lapsen äidit. Isillä ei todettu vastaavaa koulutuksellista eroa lasten lukumäärän suhteen. Kaksi kolmasosaa vanhemmista koki taloudellisen tilanteensa hyväksi. Useamman lapsen vanhemmat raportoivat yhden lapsen vanhempia useammin korkeintaan kohtalaisesta tai huonosta taloudellisesta tilanteesta. Taloudellisen tilanteen heikkenemisestä koronaepidemian vuoksi raportoi isompi osa äideistä kuin isistä.

\section{ODOTUSAIKAAN JA SYNNYTYKSEEN LIITTYVÄT HUOLET}

Kyselyyn vastanneiden vauvojen äideistä selvästi suurempi osa kuin isistä kertoi olleensa koronaepidemian takia huolissaan sekä lapsen odotukseen että synnytykseen liittyvistä asioista (Taulukko 2). Reilusti yli puolet äideistä oli ollut huolissaan synnytyksen sujumisesta ja synnytyssairaalassa olosta, kun isistä nämä huolettivat reilua kolmasosaa. Lähes puolelle äideistä mutta vain vajaalle kolmasosalle isistä huolta oli tuot- 
Taulukko 1. FinLapset-kyselytutkimukseen syksyllä 2020 vastanneiden vauvaperheiden äitien ja isien taustatiedot perheen lapsiluvun mukaan

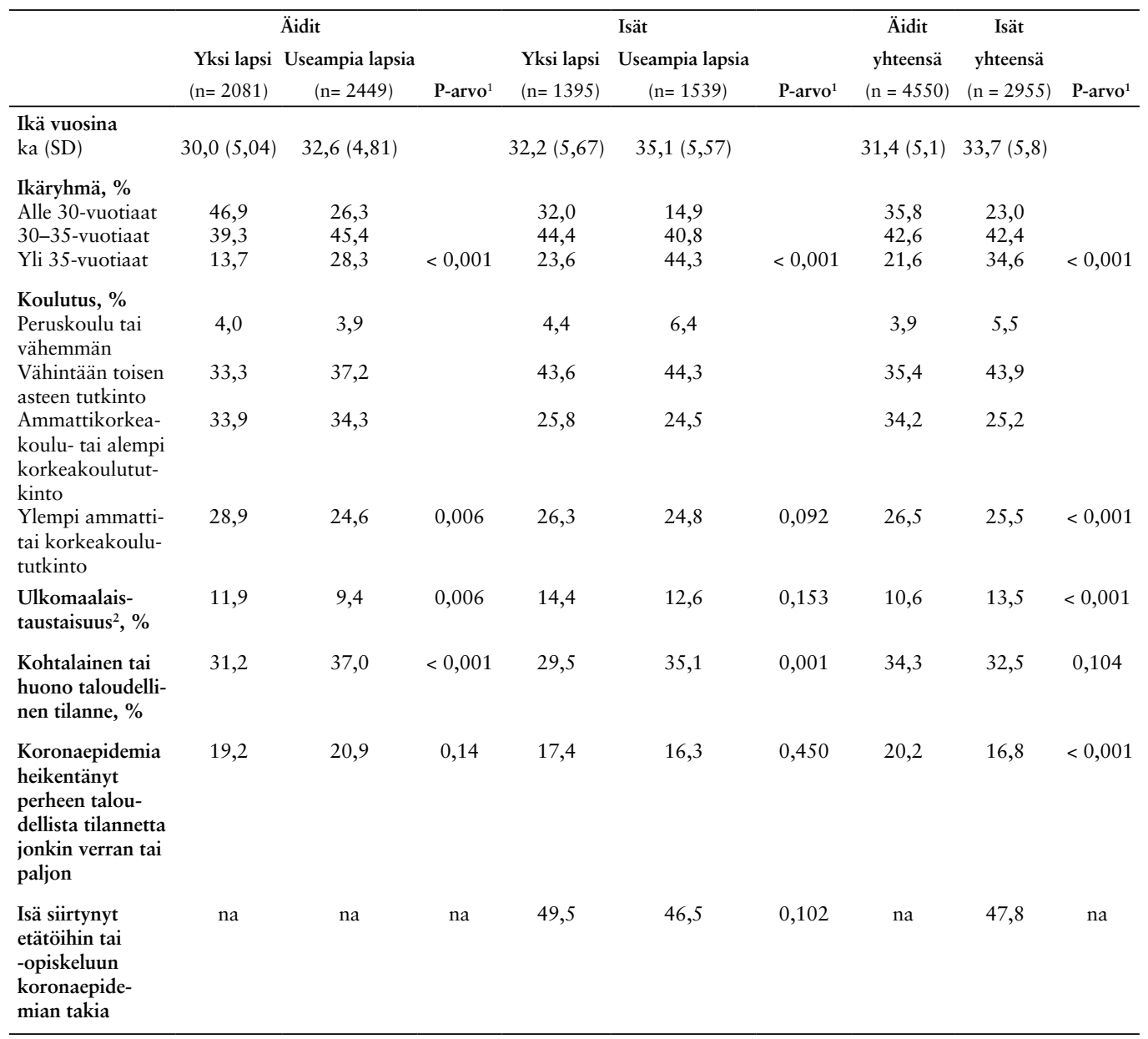

${ }^{1}$ P-arvo Khiin neliötestissä

${ }^{2}$ Syntymämaa muu kuin Suomi

Puuttuvat tiedot: 1) lasten lukumäärä: äidit $n=20$ ja isät $n=21,2$ ) koulutus: äidit $n=18$ ja isät $n=10$ ja 3) taloudellinen tilanne: äidit $\mathrm{n}=31$ ja isät $\mathrm{n}=37,4)$ koronaepidemia heikentänyt taloudellista tilannetta: äidit $\mathrm{n}=20$ ja isät $\mathrm{n}=35,5$ ) siirtyminen etätyöhön: isät $\mathrm{n}=66$

na tieto ei käytettävissä

tanut odotusajan sujuminen korona-aikana sekä koronaviruksen vaarallisuus sikiölle tai vauvalle. Kaikki nämä huolestuttivat erityisesti ensimmäisen lapsen saaneita vanhempia sekä niitä, joiden taloudellinen tilanne oli korkeintaan kohtalainen (Liitetaulukko). Yleisintä synnytyksen sujumisesta $(65 \%)$ ja synnytyssairaalassa oloajasta $(64 \%)$ huolissaan oleminen oli nuorten, alle 30-vuotiaiden äitien ryhmässä (Liitetaulukko).

Kun yhden lapsen vanhempien huolestuneisuutta verrattiin useamman lapsen vanhempiin vakioimalla ikä, koulutus ja taloudellinen tilanne, säilyi yhteys lapsilukuun niin, että ensimmäistä lastaan odottavilla äideillä ja isillä oli suurempi riski olla huolissaan (Taulukko 4). Vakioitu ristitulosuhde (aOR) huolestuneisuudesta synnytyssairaalassa oloajasta oli äideillä 2,12 (95\% LV,1,86-2,41) ja isillä 2,09 $(1,78-2,46)$ ja synnytyksen sujumisesta äideillä 1,98 (1,74-2,25) ja isillä 1,95 (1,66-2,30). 
Taulukko 2. Koronaepidemian aiheuttama huolestuneisuus vauvaperheissä vanhemmuuden ja perheen lapsiluvun mukaan syksyllä 2020 FinLapset-kyselytutkimukseen vastanneilla, \%

\begin{tabular}{|c|c|c|c|c|c|c|c|c|c|}
\hline \multirow{2}{*}{$\begin{array}{l}\text { Huolestuneisuus } \\
\text { (melko tai } \\
\text { hyvin paljon } \\
\text { huolissaan) }\end{array}$} & \multicolumn{2}{|c|}{ Äidit $^{1}$} & \multicolumn{4}{|c|}{ Isät $^{1}$} & \multirow{2}{*}{$\begin{array}{c}\text { Äidit }^{1} \\
\text { yhteensä } \\
(\mathrm{n}=4550)\end{array}$} & \multirow{2}{*}{$\begin{array}{c}\text { Isät }^{1} \\
\text { yhteensä } \\
(\mathrm{n}=2995) \\
\end{array}$} & \multirow[b]{2}{*}{$\mathrm{P}$-arvo ${ }^{2}$} \\
\hline & $\begin{array}{l}\text { Yksi lapsi } \\
(\mathrm{n}=2081)\end{array}$ & $\begin{array}{c}\text { Useampia } \\
\text { lapsia } \\
(n=2449)\end{array}$ & P-arvo ${ }^{2}$ & $\begin{array}{l}\text { Yksi lapsi } \\
(\mathrm{n}=1395)\end{array}$ & $\begin{array}{c}\text { Useampia } \\
\text { lapsia } \\
(\mathrm{n}=1539)\end{array}$ & P-arvo ${ }^{2}$ & & & \\
\hline $\begin{array}{l}\text { Koronavirustartun- } \\
\text { nan saaminen (itse } \\
\text { tai perheenjäsen) }\end{array}$ & 34,2 & 30,2 & $<0,010$ & 21,1 & 17,6 & 0,015 & 32,0 & 19,3 & $<0,001$ \\
\hline $\begin{array}{l}\text { Muiden } \\
\text { tartuttaminen }\end{array}$ & 19,7 & 19,4 & 0,750 & 15,5 & 13,3 & 0,100 & 19,6 & 14,4 & $<0,001$ \\
\hline $\begin{array}{l}\text { Vauvan odotusajan } \\
\text { sujuminen korona- } \\
\text { epidemian aikana }\end{array}$ & 51,2 & 41,1 & $<0,001$ & 33,5 & 23,2 & $<0,001$ & 45,8 & 28,0 & $<0,001$ \\
\hline $\begin{array}{l}\text { Synnytyksen } \\
\text { sujuminen korona- } \\
\text { epidemian aikana }\end{array}$ & 69,1 & 52,2 & $<0,001$ & 44,4 & 30,5 & $<0,001$ & 60,0 & 37,1 & $<0,001$ \\
\hline $\begin{array}{l}\text { Synnytyssairaalassa } \\
\text { oloaika korona- } \\
\text { epidemian aikana }\end{array}$ & 69,1 & 50,8 & $<0,001$ & 44,8 & 28,9 & $<0,001$ & 59,2 & 36,4 & $<0,001$ \\
\hline $\begin{array}{l}\text { Koronaviruksen } \\
\text { vaarallisuus sikiölle } \\
\text { tai vauvalle }\end{array}$ & 52,4 & 40,1 & $<0,001$ & 37,3 & 25,1 & $<0,001$ & 45,8 & 30,8 & $<0,001$ \\
\hline
\end{tabular}

\footnotetext{
${ }^{1}$ Kysymyskohtainen vastaajamäärä voi poiketa

${ }^{2} \mathrm{P}$-arvo Khiin neliötestissä

${ }^{3}$ Ristiintaulukoissa ja Khin neliötesteissä olivat mukana myös "Korkeintaan kohtalaisesti huolissaan” vastanneiden ryhmät
}

\section{VANHEMPIEN KOKEMUKSET KORONAEPIDEMIAN JA SEN RAJOITTAMISTOIMIEN VAIKUTUKSESTA PERHEEN ARKEEN}

\section{Jaksaminen}

Vauvojen äideistä ja isistä suurin osa $(60 \%$ ja $70 \%$ ) koki, etteivät koronaepidemia tai sen rajoittamistoimet olleet muuttaneet arjessa jaksamista (Taulukko 3). Erityisesti äitien jaksaminen koronaepidemian vuoksi oli melko polarisoitunutta: osalla äideistä jaksaminen oli vähentynyt $(25 \%)$ ja osalla puolestaan lisääntynyt (16\%). Isillä vastaavat osuudet olivat $18 \%$ ja $12 \%$. Polarisoituminen oli yleisempää useamman lapsen äideillä kuin yhden lapsen äideillä. Isillä lasten lukumäärä ei ollut yhteydessä muutoksiin jaksamisessa. Jaksamisen muutokset koronaepidemian vuoksi polarisoituivat myös korkeintaan kohtalaisessa taloudellisessa tilanteessa olevilla vanhemmilla, erityisesti äideillä: verrattuna hyvässä taloudellisessa tilanteessa oleviin suurempi osa tässä ryhmässä raportoi sekä jaksamisen lisääntymisestä että vähenemisestä (Liitetaulukko). Jaksamisen arjessa raportoi vähentyneen suurempi osa korkeammin koulutetuista kuin matalammin koulutetuista vanhemmista ( $31 \%$ vs. $14 \%$ ) ja yli 30-vuotiaista äideistä kuin nuoremmista äideistä $(27 \%$ vs. $20 \%$ ). Iän, koulutuksen ja taloudelli- sen tilanteen vakioiminen ei muuttanut tuloksia, kun verrattiin yhden ja useamman lapsen vanhempien kokemuksia arjessa jaksamisen muutoksista koronaepidemian takia (Taulukko 4).

\section{Parisuhde ja perheen yhteinen aika}

Suurin osa vauvojen äideistä $(82 \%)$ ja isistä (84\%) koki, etteivät koronaepidemia tai sen rajoittamistoimet olleet vaikuttaneet puolisoiden välisiin ristiriitoihin ja erimielisyyksiin (Taulukko 3). Niiden vanhempien mielestä, joiden mukaan epidemia tai rajoitustoimet vaikuttivat jollain lailla puolisoiden välisiin suhteisiin, vaikutus oli ollut useammalla kielteinen kuin myönteinen eli ristiriidat ja erimielisyydet puolisoiden välillä olivat useammalla lisääntyneet kuin vähentyneet. Erimielisyyksien lisääntymisestä raportoi suurempi osa useamman lapsen kuin yhden lapsen vanhemmista (Taulukko 3) ja korkeintaan kohtalaisessa taloudellisessa tilanteessa olevista kuin hyvässä taloudellisessa tilanteessa olevista vanhemmista (Liitetaulukko). Kun yhden lapsen ja useamman lapsen vanhempien kokemusta puolisoiden välisten erimielisyyksien lisääntymisestä verrattiin vakioimalla ikä, koulutus ja taloudellinen tilanne, säilyi yhteys lapsilukuun niin, että useamman lapsen vanhemmilla oli suurempi riski eri- 
Taulukko 3. Koronaepidemian arjessa tapahtuneet koetut muutokset vauvaperheissä vanhemmuuden ja perheen lapsiluvun mukaan syksyllä 2020 FinLapset-kyselytutkimukseen vastanneilla, \%

\begin{tabular}{|c|c|c|c|c|c|c|c|c|c|}
\hline \multirow{2}{*}{$\begin{array}{l}\text { Kokemus arjessa } \\
\text { tapahtuneista } \\
\text { muutoksista }\end{array}$} & \multicolumn{2}{|c|}{ Äidit $^{1}$} & \multicolumn{4}{|c|}{ Isät $^{1}$} & \multirow{2}{*}{$\begin{array}{c}\text { Äidit }^{1} \\
\text { yhteensä } \\
(\mathrm{n}=4550)\end{array}$} & \multirow{2}{*}{$\begin{array}{c}\text { Isät }^{1} \\
\text { yhteensä } \\
(\mathrm{n}=2995)\end{array}$} & \multirow[b]{2}{*}{$\mathrm{P}$-arvo ${ }^{2}$} \\
\hline & $\begin{array}{l}\text { Yksi lapsi } \\
(\mathrm{n}=2081)\end{array}$ & $\begin{array}{c}\text { Useampia } \\
\text { lapsia } \\
(n=2449)\end{array}$ & $\mathrm{P}$-arvo ${ }^{2}$ & $\begin{array}{l}\text { Yksi lapsi } \\
(\mathrm{n}=1395)\end{array}$ & $\begin{array}{c}\text { Useampia } \\
\text { lapsia } \\
(\mathrm{n}=1539)\end{array}$ & $\mathrm{P}$-arvo ${ }^{2}$ & & & \\
\hline Jaksaminen arjessa & & & $<0,001$ & & & 0,744 & & & $<0,001$ \\
\hline Ei vaikutusta & 67,3 & 53,6 & & 70,6 & 69,7 & & 59,8 & 70,1 & \\
\hline Lisääntynyt & 12,8 & 17,7 & & 12,3 & 12,1 & & 15,5 & 12,2 & \\
\hline Vähentynyt & 19,9 & 28,7 & & 17,1 & 18,2 & & 24,7 & 17,7 & \\
\hline $\begin{array}{l}\text { Puolisoiden väliset } \\
\text { erimielisyydet ja } \\
\text { ristiriidat }\end{array}$ & & & $<0,001$ & & & $<0,001$ & & & 0,014 \\
\hline Ei vaikutusta & 84,6 & 79,0 & & 85,8 & 81,5 & & 81,5 & 83,5 & \\
\hline Lisääntyneet & 12,6 & 16,8 & & 10,0 & 14,7 & & 14,9 & 12,5 & \\
\hline Vähentyneet & 2,8 & 4,2 & & 4,2 & 3,8 & & 3,6 & 4,0 & \\
\hline $\begin{array}{l}\text { Puolisoiden välinen } \\
\text { läheisyyden tunne }\end{array}$ & & & 0,057 & & & $<0,001$ & & & 0,127 \\
\hline Ei vaikutusta & 77,3 & 74,6 & & 78,1 & 77,7 & & 75,8 & 77,9 & \\
\hline Lisääntynyt & 16,9 & 18,1 & & 17,8 & 14,8 & & 17,6 & 16,2 & \\
\hline Vähentynyt & 5,8 & 7,3 & & 4,1 & 7,5 & & 6,6 & 5,9 & \\
\hline $\begin{array}{l}\text { Perheen kanssa vietetyn } \\
\text { ajan määrä }\end{array}$ & & & $<0,001$ & & & $<0,001$ & & & $<0,001$ \\
\hline Ei vaikutusta & 44,6 & 35,5 & & 48,1 & 43,5 & & 39,8 & 45,6 & \\
\hline Lisääntynyt & 35,1 & 58,3 & & 44,3 & 53,6 & & 47,6 & 49,1 & \\
\hline Vähentynyt & 20,3 & 6,2 & & 7,6 & 2,9 & & 12,6 & 5,2 & \\
\hline $\begin{array}{l}\text { Yhteydenpito } \\
\text { isovanhempiin }\end{array}$ & & & $<0,001$ & & & 0,002 & & & $<0,001$ \\
\hline Ei vaikutusta & 44,5 & 39,1 & & 48,5 & 45,0 & & 41,6 & 46,6 & \\
\hline Lisääntynyt & 15,5 & 12,3 & & 14,4 & 11,7 & & 13,7 & 13,0 & \\
\hline Vähentynyt & 40,0 & 48,6 & & 37,1 & 43,3 & & 44,7 & 40,4 & \\
\hline Yhteydenpito ystäviin & & & $<0,001$ & & & 0,162 & & & $<0,001$ \\
\hline Ei vaikutusta & 32,6 & 27,8 & & 36,2 & 36,9 & & 30,0 & 36,7 & \\
\hline Lisääntynyt & 8,2 & 7,0 & & 6,1 & 4,5 & & 7,6 & 5,2 & \\
\hline Vähentynyt & 59,2 & 65,2 & & 57,6 & 58,5 & & 62,5 & 58,1 & \\
\hline Yksinäisyyden tunne & & & 0,184 & & & 0,688 & & & $<0,001$ \\
\hline Ei vaikutusta & 48,9 & 51,4 & & 76,3 & 77,7 & & 50,2 & 77,0 & \\
\hline Lisääntynyt & 49,1 & 46,3 & & 21,9 & 20,8 & & 47,5 & 21,3 & \\
\hline Vähentynyt & 2,1 & 2,3 & & 1,8 & 1,6 & & 2,2 & 1,7 & \\
\hline
\end{tabular}

${ }^{1}$ Kysymyskohtainen vastaajamäärä voi poiketa

${ }^{2}$ P-arvo Khiin neliötestissä

mielisyyksien lisääntymiselle (äideillä $\mathrm{aOR}=$ $0,71(0,59-0,86)$ ja isillä aOR=0,66(0,52-0,84)) (Taulukko 4).

Suurin osa vauvojen äideistä $(76 \%)$ ja isistä $(78 \%)$ koki, etteivät koronaepidemia tai sen rajoittamistoimet olleet vaikuttaneet puolisoiden väliseen läheisyyden tunteeseen (Taulukko 3). Puolisoiden välinen läheisyyden tunne oli lisääntynyt vajaalla viidesosalla vauvojen vanhemmista ja vähentynyt alle kymmenellä prosentilla. Läheisyyden tunteen lisääntymisestä raportoi suurempi osa korkeasti koulutetuista kuin matalasti koulutetuista vanhemmista ja vä- hentymisestä useampi korkeintaan kohtalaisessa taloudellisessa asemassa olevista kuin hyvässä taloudellisessa tilanteessa olevista (Liitetaulukko). Kun yhden ja useamman lapsen vanhempien kokemusta läheisyyden tunteen muutoksista verrattiin niin, että ikä, koulutus ja taloudellinen tilanne vakioitiin, todettiin, että useamman lapsen isillä oli muita isä suurempi riski läheisyyden tunteen vähentymiseen $(\mathrm{aOR}=0,63(0,44-0,89))$ (Taulukko 4). Vastaavaa vaikutusta ei havaittu äitien vastausten pohjalta.

Vauvojen äideistä ja isistä selvästi vajaa puolet $(40 \%$ ja $46 \%)$ koki, ettei koronaepidemia 
Taulukko 4. Koronaepidemian aiheuttamat huolestuneisuus ja koetut arjessa tapahtuneet muutokset vauvaperheissä, joissa ei ole vauvan lisäksi muita lapsia.

Vakioitu ristitulosuhde (aOR) ${ }^{1}$ ja 95 \% luottamusväli (LV) FinLapset-kyselytutkimuksessa 2020

\begin{tabular}{lcccc}
\hline & \multicolumn{2}{c}{ Äidit } & \multicolumn{2}{c}{ Isät } \\
Huolestuneisuus (melko tai hyvin paljon huolissaan) & $\mathrm{aOR}^{1}$ & $95 \% \mathrm{LV}$ & $\mathrm{aOR}^{1}$ & $95 \% \mathrm{LV}$ \\
\hline Koronavirustartunnan saaminen (itse tai perheenjäsen) & 1,30 & $1,14-1,49$ & 1,42 & $1,17-1,73$ \\
Muiden tartuttaminen & 1,02 & $0,88-1,20$ & 1,28 & $1,03-1,60$ \\
Vauvan odotusajan sujuminen koronaepidemian aikana & 1,48 & $1,31-1,67$ & 1,84 & $1,55-2,19$ \\
Synnytyksen sujuminen koronaepidemian aikana & 1,98 & $1,74-2,25$ & 1,95 & $1,66-2,30$ \\
Synnytyssairaalassa oloaika koronaepidemian aikana & 2,12 & $1,86-2,41$ & 2,09 & $1,78-2,46$ \\
Koronaviruksen vaarallisuus sikiölle tai vauvalle & 1,66 & $1,47-1,89$ & 1,97 & $1,67-2,34$ \\
Arjessa tapahtuneet muutokset & & & & \\
Jaksaminen arjessa lisääntynyt & & & & $0,84-1,37$ \\
Jaksaminen arjessa vähentynyt & 0,59 & $0,49-0,70$ & 1,07 & $0,74-1,13$ \\
Puolisoiden valiset erimielisyydet ja ristiriidat lisääntyneet & 0,56 & $0,48-0,65$ & 0,92 & $0,52-0,84$ \\
Puolisoiden väliset erimielisyydet ja ristiriidat vähentyneet & 0,71 & $0,59-0,86$ & 0,66 & $0,72-1,59$ \\
Puolisoiden välinen laheisyyden tunne lisääntynyt & 0,68 & $0,48-0,97$ & 1,07 & $0,98-1,50$ \\
Puolisoiden välinen laheisyyden tunne vähentynyt & 0,90 & $0,76-1,07$ & 1,21 & $0,44-0,89$ \\
Perheen kanssa vietetyn ajan määrä lisääntynyt & 0,83 & $0,64-1,08$ & 0,63 & $0,63-0,87$ \\
Perheen kanssa vietetyn ajan määrä vähentynyt & 0,48 & $0,42-0,56$ & 0,74 & $1,51-3,27$ \\
Yhteydenpito isovanhempiin lisääntynyt & 2,63 & $2,11-3,28$ & 2,22 & $0,94-1,54$ \\
Yhteydenpito isovanhempiin vähentynyt & 1,17 & $0,96-1,42$ & 1,20 \\
Yhteydenpito ystäviin lisääntynyt & 0,75 & $0,65-0,86$ & 0,88 & $0,74-1,04$ \\
Yhteydenpito ystäviin vähentynyt & 1,07 & $0,84-1,38$ & 1,63 & $1,13-2,33$ \\
Yksinäisyyden tunne lisääntynyt & 0,82 & $0,72-0,95$ & 1,12 & $0,95-1,33$ \\
Yksinäisyyden tunne vähentynyt & 1,13 & $0,99-1,28$ & 1,06 & $0,87-1,30$ \\
\hline I OR & 0,98 & $0,63-1,52$ & 1,14 & $0,61-2,14$ \\
\hline
\end{tabular}

${ }^{1} \mathrm{aOR}=$ adjusted odds ratio: vakioitu ikä, koulutus ja vanhemman koettu taloudellinen tilanne

Arjessa tapahtuneet muutokset: tulokset multinomiaalisesta logistisesta regressiosta, jossa viiteluokkana "ei vaikutusta"

Äidit $N=4530$ (yksi lapsi $n=2081$, useampia lapsia $n=2449$ ), isät $N=2934$ (yksi lapsi $n=1395$, useampia lapsia $n=1539$ )

Referenssiryhmä = perheet, joissa on vauvan lisäksi muita lapsia

ollut vaikuttanut perheen kanssa vietetyn ajan määrään (Taulukko 3). Suurempi osa vanhemmista koki perheen kanssa vietetyn ajan lisääntyneen kuin vähentyneen: lähes puolet vanhemmista koki yhteisen ajan lisääntyneen ja vain $13 \%$ äideistä ja $5 \%$ isistä koki yhteisen ajan vähentyneen. Etätöihin siirtyneistä isistä peräti $67 \%$ koki yhteisen ajan lisääntyneen.

Perheen yhteisen ajan lisääntymisestä raportoi suurempi osa korkeasti koulutetuista kuin matalasti koulutetuista ja useamman lapsen kuin yhden lapsen vanhemmista (Taulukko 3) sekä hyvässä taloudellisessa tilanteessa olevista kuin korkeintaan kohtalaisessa taloudellisessa tilanteessa olevista isistä (Liitetaulukko). Kaksi kolmesta ylemmän korkeakoulututkinnon suorittaneesta vanhemmasta koki yhteisen ajan määrän lisääntyneen, kun vastaava osuus korkeintaan peruskoulun suorittaneista oli noin kolmannes. Kun yhden ja useamman lapsen vanhempien kokemusta perheen yhteisen ajan lisääntymisestä verrattiin vakioimalla ikä, koulutus ja taloudellinen tilanne, säilyi yhteys lapsiluvun välillä niin, että useamman lapsen vanhemmilla kokemus perheen yhteisen ajan lisääntymisestä oli todennäköisempää (äideillä aOR=0,48(0,42-0,56) ja isillä aOR=0,74(0,63-0,87)) (Taulukko 4).

Kokemuksesta perheen yhteisen ajan vähentymisestä raportoi suurempi osa yhden kuin useamman lapsen vanhemmista (Taulukko 3) ja korkeintaan kohtalaisessa taloudellisessa tilanteessa olevista kuin hyvässä taloudellisessa tilanteessa olevista äideistä (Liitetaulukko). Kun yhden ja useamman lapsen vanhempien kokemusta yhteisen ajan vähentymisestä verrattiin vakioimalla ikä, koulutus ja taloudellinen tilanne, yhden lapsen vanhemmilla oli selvästi suurempi riski yhteisen ajan vähentymiseen (äideillä aOR=2,63(2,11-3,28) ja isillä aOR=2,22(1,51$3,27)$ ) (Taulukko 4).

\section{Sosiaaliset suhteet ja yksinäisyys}

Koronaepidemia tai sen rajoittamistoimet eivät olleet vaikuttaneet kaikkien vauvaperheiden sosiaalisiin suhteisiin, sillä vajaa puolet vanhemmista (42\% äideistä ja $47 \%$ isistä) koki, ettei yhtey- 
denpito vauvan isovanhempiin ollut muuttunut (Taulukko 3). Äideistä kolmasosa ja isistä reilu kolmannes (37 \%) koki, ettei yhteydenpito myöskään ystäviin ollut muuttunut. Vanhemmista huomattavasti suurempi osa koki kuitenkin yhteydenpidon ystäviin ja isovanhempiin vähentyneen kuin lisääntyneen. Äideistä $45 \%$ ja isistä $40 \%$ piti koronaepidemian vuoksi aiempaa vähemmän yhteyttä isovanhempiin; useamman lapsen vanhemmista näin raportoi suurempi osa kuin yhden lapsen vanhemmista. Yhteydenpito ystäviin oli vähentynyt kahdella kolmasosalla äideistä ja isistä; useamman lapsen äideistä suuremmalla osalla kuin yhden lapsen äideistä.

Taloudellisella tilanteella ei ollut selvää yhteyttä yhteydenpidon vähenemiseen ystävien ja isovanhempien kanssa, mutta vanhemman koulutus ja ikä olivat niihin yhteydessä (Liitetaulukko). Ylemmän korkeakoulututkinnon suorittaneista noin puolet koki vähentäneensä yhteydenpitoa isovanhempiin, kun osuus enintään peruskoulututkinnon suorittaneista oli noin kolmannes. Vastaavasti yhteydenpitoa ystäviin koki vähentäneensä ylemmän korkeakoulututkinnon suorittaneista noin kaksi kolmesta ja enintään peruskoulun suorittaneista reilut $40 \%$ vanhemmista.

Yli 35-vuotiaista vanhemmista noin puolet koki yhteydenpidon isovanhempiin vähentyneen ja alle 30-vuotiaista noin kolmannes (Liitetaulukko). Ystävien kanssa yhteydenpidon koki vähentyneen noin kaksi kolmesta yli 30-vuotiaasta ja yli puolet alle 30-vuotiaista äideistä sekä alle puolet alle 30-vuotiaista isistä.

Kun verrattiin yhden ja useamman lapsen isien kokemuksia yhteydenpidon vähentymisestä isovanhempiin ja ystäviin niin, että ikä, koulutus ja taloudellinen tilanne vakioitiin, tilastollisesti merkitseviä yhteyksiä ei todettu (Taulukko 4). Äideillä yhteydenpidon vähentyminen oli myös vakioinnin jälkeen yhteydessä yhteydenpitoon niin, että useamman lapsen äideillä oli suurempi riski vähentää yhteydenpitoa isovanhempiin $(\mathrm{aOR}=$ $0,75(0,65-0,86))$ ja ystäviin $(\mathrm{aOR}=0,82(0,72-$ $0,95))$.

Vauvojen äideistä puolet ja isistä suurin osa $(77 \%)$ koki, etteivät koronaepidemia tai sen rajoittamistoimet olleet vaikuttaneet yksinäisyyden tunteen lisääntymiseen (Taulukko 3). Yksinäisyyden tunteen koki koronaepidemian takia lisääntyneen selvästi useampi vauvan äiti $(48 \%)$ kuin isä $(21 \%)$. Yksinäisyyden tunteen lisääntymisestä raportoi myös hieman useampi korkeintaan kohtalaisessa taloudellisessa tilanteessa olevista vanhemmista kuin hyvässä taloudellisessa tilanteessa olevista (Liitetaulukko). Myös koulutuksella oli merkittävä yhteys kokemukseen yksinäisyyden tunteen lisääntymisestä erityisesti äitien keskuudessa. Ylemmän korkeakoulututkinnon suorittaneista äideistä puolet, mutta enintään peruskoulun suorittaneista reilu kolmannes koki yksinäisyyden tunteen lisääntyneen. Lasten määrä ei ollut yhteydessä vanhempien kokemukseen yksinäisyyden tunteen muutoksista koronaepidemian takia (Taulukko 3) eikä iän, koulutuksen ja taloudellisen tilanteen vakiointi muuttanut tuloksia (Taulukko 4).

\section{КАTO}

Vastaamatta jättäneistä äideistä alle 30-vuotiaita oli $42 \%, 30-35$-vuotiaita $33 \%$ ja yli 35 -vuotiaita $25 \%$. Isillä vastaavat luvut olivat $27 \%, 33 \%$ ja $40 \%$. Keski-ikä oli vastaamatta jättäneillä äideillä 30,7 (SD 5,4) ja isillä 33,4 (SD 6,2) vuotta. Ulkomaalaistaustaisia vastaamatta jättäneistä äideistä oli $22 \%$ ja isistä $18 \%$. Keski-ikä ei siis poikennut juurikaan vastanneiden keski-iästä, mutta vastanneissa oli vastaamatta jättäneitä hieman enemmän vanhempiin ikäluokkiin kuuluvia ja vähemmän ulkomaalaistaustaisia äitejä ja isiä (Taulukko 1).

Tilastokeskuksen erillisaineistossa, jossa olivat kaikkien 20.4.-12.7.2020 välillä syntyneiden vauvojen vanhempien koulutustiedot aggregaattitasolla, peruskoulun tai vähemmän suorittaneita äitejä oli $9 \%$, vähintään toisen asteen tutkinnon suorittaneita $40 \%$, ammattikorkeakoulu- tai alemman korkeakoulututkinnon suorittaneita $28 \%$ ja ylemmän ammatti- tai korkeakoulututkinnon suorittaneita $19 \%$. Isillä vastaavat luvut olivat $15 \%, 50 \%, 19 \%$ ja $16 \%$. Vastanneet olivat siis selvästi harvemmin pelkän peruskoulun suorittaneita ja useammin korkeakoulututkinnon suorittaneita kuin samana aikana syntyneiden vauvojen vanhemmat (Taulukko 3). Tosin osa vanhemmista on voinut saada tutkinnon valmiiksi vuoteen 2020 mennessä.

Tilastokeskuksen erillisaineistoon verrattuna FinLapset-kyselyaineiston DVV:n otosten kattavuus oli naisilla $87 \%$ ja vaihteli maakunnittain 84-99 \% välillä. Miehillä vastaava osuus oli $81 \%$ ja maakunnittainen vaihtelu välillä 77-90\%. 


\section{POHDINTA}

Vauvaperheille suunnatun FinLapset-kyselytutkimuksen mukaan koronaepidemialla on ollut sekä kielteiseksi että myönteisiksi koettuja vaikutuksia niin yhden kuin useamminkin lapsen vauvaperheiden hyvinvointiin. Kokemukset vaikutuksista vauvaperheiden arkeen tulivat selvemmin esiin äitien kuin isien vastauksissa. Perheiden hyvinvoinnin polarisoituminen näkyi useamman lapsen vanhempien jaksamisessa; yhtäältä kokemus jaksamisen lisääntymisestä ja toisaalta kokemus jaksamisen vähentymisestä oli heillä muita yleisempää. Koronaepidemia huolestutti kuitenkin selvästi enemmän yhden lapsen vanhempia. Heidän huolensa liittyivät erityisesti synnytyksen sujumiseen ja synnytyssairaalassa oloon koronaaikana. Lisäksi perheen kanssa vietetty aika oli etenkin heidän kokemuksensa mukaan vähentynyt. Kokemus puolisoiden välisen läheisyyden tunteen lisääntymisestä ei ollut yhteydessä siihen, oliko perheessä vauvan lisäksi muita lapsia, mutta kokemus läheisyyden tunteen vähenemisestä oli useamman lapsen isillä hieman yleisempää kuin yhden lapsen isillä. Vanhempien kokemuksen mukaan erimielisyydet ja ristiriidat lisääntyivät yleisemmin useamman kuin yhden lapsen vanhemmilla.

\section{TUTKIMUKSEN VAHVUUDET JA RAJOITUKSET}

Tutkimuksen vahvuutena on se, että on kyse erittäin laajasta kansallisesta, koko Suomessa tiettynä aikana syntyneiden vauvojen vanhemmille suunnatusta tutkimuksesta, jossa etenkin äitien vastausaktiivisuutta voidaan pitää hyvänä (50\%). Isien vastausaktiivisuus jäi alhaisemmaksi. Tulokset voivat antaa todellisuutta myönteisemmän kuvan vauvaperheiden huolista ja kokemuksista arjesta korona-aikana, koska vastanneet olivat jonkin verran vanhempia, korkeammin koulutettuja ja useammin suomalaistaustaisia kuin vastaamatta jättäneet. Toisaalta esimerkiksi kokemus yksinäisyyden tunteen lisääntymisestä oli tutkimuksessamme yleisintä juuri korkeasti koulutetuilla, joten asia ei ole ihan suoraviivainen. Aineiston sisäiseen tarkasteluun eroilla vastaajien ja vastaamatta jättäneiden välillä ei ole merkitystä etenkin, kun logistisessa regressiossa vakioitiin vanhempien ikä, koulutus ja taloudellinen tilanne.

Koronaan liittyviä huolia ja kokemuksia koronan vaikutuksista vauvaperheiden arkeen kysyttiin vanhemmilta osin samoilla kysymyksillä kuin väestöltä on kysytty muissa väestökyselyissä (34-36), joten niiltä osin vastauksia voidaan tietyin varauksin verrata muihin aikuisväestön tutkimuksiin. Osin kysymyksiä muokattiin soveltuvaksi nimenomaan vauvaperheille. Huolikysymyksen taustalla oli kansainvälinen mittari, mutta kokemuksia koronan vaikutuksista mitattiin THL:lla kehitetyllä kysymyspatteristolla, koska validoitua kansainvälistä mittaria ei ollut käytettävissä. Tietääksemme vastaavaa tutkimusta ei ole muualla tehty vauvaperheille, joten niiltä osin vertailu ei ole mahdollista.

Tutkimuksen rajoituksena on se, että Digi- ja väestötietoviraston niin sanottu huoltajataulu, jonka avulla tiettynä aikana syntyneet vauvat ja heidän vanhempansa poimittiin eri otoksiin, ei ollut poimintojen aikana vielä täydellinen. Otoksista jäivät pois markkinointikiellon antaneet vanhemmat. Tilastokeskuksen aineistoon verrattuna kattavuus oli kuitenkin hyvä. Se ja erityisesti äitien korkeahko vastausaktiivisuus lisäävät tulosten luotettavuutta ja yleistettävyyttä. Validoitujen mittareiden puute puolestaan heikentää luotettavuutta, mutta toisaalta vastaavia kysymyksiä oli jo käytetty muissa suomalaistutkimuksissa. Tutkimuksen heikkoutena ovat myös poikkileikkaustutkimuksen käyttö ja se, että käytetyt mittarit olivat hyvin subjektiivisia. Toisaalta tarkoitus oli tutkia nimenomaan vanhempien subjektiivisia kokemuksia koronan aiheuttamista huolista ja vaikutuksista perheen arkeen.

\section{KORONAEPIDEMIAN AIHEUTTAMA HUOLESTUNEISUUS}

Koronaepidemian myötä kaikki ihmiset joutuivat uuden tilanteen eteen, kun arkielämä muuttui niin ansiotyön, sosiaalisen vuorovaikutuksen kuin monien palvelujenkin osalta (5,15-19). Ensimmäisen lapsen myötä vanhempien elämä muuttuu ennen kokemattomalla tavalla, äitien osalta usein vielä enemmän kuin isien johtuen raskauden, synnytyksen ja imetyksen psykofyysisistä vaikutuksista sekä jäämisestä ansiotyöstä kotiin perhevapaalle $(7,8,32)$. Koronaepidemia toi mukaan yhtälöön riskin tartunnasta ja sairastumisesta sekä myös lomautus- ja irtisanomisriskin työelämässä $(5,32)$.

Huoli toisten tartuttamisesta ja tartunnan saamisesta ei ollut vauvaperheiden vanhemmilla yhtä suuri kuin työikäisellä väestöllä keskimäärin syksyllä 2020 (36). Vauvaperheiden äidit olivat pääsääntöisesti vanhempainvapaalla, hyvin 
monet isät etätöissä ja sosiaalisia suhteita oli karsittu, joten on ymmärrettävää, että heitä huolestuttivat enemmän juuri omaan, erityiseen elämäntilanteeseensa liittyvät asiat kuten koronan vaikutukset odotukseen ja synnytykseen. Huolta lisäsi todennäköisesti se, että kaikkien syksyn otosten äitien raskaus oli osittain ajoittunut korona-aikaan ja osa vauvoista oli syntynyt aikana, jolloin äitiysneuvoloiden palveluja supistettiin (39) ja synnytyssairaalat rajoittivat tukihenkilön läsnäoloa synnytyssairaaloissa (19). On myös hyvin ymmärrettävää, että nämä huolestuttivat erityisesti ensimmäisen lapsen saaneita vanhempia (32).

\section{KORONAEPIDEMIAN VAIKUTUKSET ARKEEN JA SOSIAALISIIN SUHTEISIIN}

Vauvaperheissä koronan vaikutukset yhdistyivät uuden perheenjäsenen mukanaan tuomiin arjen muutoksiin $(5,32)$. Esikoisen myötä kahden aikuisen ajankäyttöön tulee uusi osapuoli ja yhteinen aika helposti vähenee toisen ollessa perhevapaalla ja toisen työelämässä tai opiskelemassa. Koronaepidemian myötä yli puolet suomalaisista palkansaajista siirtyi etätyöhön, reilulla neljäsosalla työaika lyheni ja viidesosalla puolestaan piteni (40). Miehet, korkeammin koulutetut ja nuoremmat ikäluokat siirtyivät muita useammin tekemään etätyötä (37).

Pienen lapsen hoito sitoo paljon vanhempien aikaa ja sen yhteensovittaminen erityisesti etätyön kanssa voi olla haastavaa (5). Mahdollisesti ajankäyttöön liittyvät odotukset samoin kuin työssäkäyvän vanhemman työpaineet olivat jonkin verran erilaisia yhden lapsen ja useamman lapsen vauvaperheissä (41), sillä yhden lapsen vanhemmat kokivat yleisemmin perheen kanssa vietetyn ajan vähentyneen koronan takia, kun taas useamman lapsen vanhemmat kertoivat useammin perheen yhteisen ajan lisääntyneen. Yhteinen aika lisääntyi vauvaperheilläkin eniten juuri niissä perheissä, joissa isä siirtyi etätöihin, ja kaiken kaikkiaan vauvaperheillä enemmän kuin työikäisellä väestöllä keskimäärin (37). Myös vauvaperheissä miehet (isät) raportoivat useammin yhteisen ajan lisääntymisestä ja naiset (äidit) sen vähentymisestä.

Sosiaalisen etäisyyden suositus tartuntariskin pienentämiseksi merkitsi kasvokkaisten tapaamisten vähenemistä sekä ystävien että sukulaisten kesken (2,5). Erityisesti varoitettiin iäkkääm- pien tapaamiseen liittyvistä riskeistä. Sosiaalisten suhteiden väheneminen oli vauvaperheissä yleisempää useamman lapsen äideillä; heillä yhteydenpito ystäviin oli vähentynyt yhden lapsen äitejä useammin. Ainoan lapsen isillä yhteydenpito ystäviin sen sijaan lisääntyi. Vaikka ensimmäisen lapsen vanhemmat ovat kokeneet ajankäytöllisesti haastavaksi ystävyyssuhteiden ylläpidon, erityisesti äidiksi tulleet (7), meidän tutkimuksemme mukaan juuri yhden lapsen vanhemmilla ja erityisesti isillä oli paras mahdollisuus pitää yhteyttä ystäviin korona-aikanakin. Voi olla, että he, useamman lapsen vanhempia nuorempina, pitivät yhteyttä ystäviin myös erilaisten sosiaalisen median kanavien kautta. Myös työikäistä väestöä koskevassa tutkimuksessa miehet kokivat naisia useammin sosiaalisten suhteidensa lisääntyneen (37). Vaikka yhteydenpito on mahdollista myös tietoverkon välityksellä, puolet vauvojen vanhemmista kertoi pitäneensä koronapandemian vuoksi aiempaa vähemmän yhteyttä lapsen isovanhempiin. Erityisesti yhteydenpitoa vähensivät korkeammin koulutetut äidit. Tämäkin on linjassa työikäisen väestön tulosten kanssa.

Monissa kansainvälisissä kyselytutkimuksissa on havaittu yksinäisyyden lisääntyneen koronaepidemian myötä erityisesti silloin, jos kasvokkaiset tapaamiset ovat vähentyneet (41). Yksinäisyyden kokemus oli lisääntynyt myös vauvaperheissä sekä yhden että useamman lapsen äideillä; eniten korkeammin koulutetuilla äideillä. Vauvaperheiden äideillä yksinäisyyden kokemus oli lisääntynyt huomattavasti useammin kuin isillä tai työikäisellä väestöllä keskimäärin $(37,38)$. Vauvaperheiden isillä tulos ei niin paljon poikennut muusta työikäisestä väestöstä, mutta myös isien joukossa korkeimmin koulutetut tunsivat useammin yksinäisyyden tunteensa lisääntyneen. Kokemus yksinäisyyden tunteen lisääntymisestä oli korkeammin koulutetuilla yleisempää varmasti osin siksi, että juuri he kertoivat tutkimuksessamme vähentäneensä sosiaalisia kontaktejaan. Vanhempien yksinäisyyden kokemuksella on vaikutusta perhedynamiikkaan, ja sillä voi olla myös yhteyttä pidemmän ajan henkiseen hyvinvointiin niin perheen aikuisilla kuin perheessä kasvavilla lapsilla $(5,43)$.

Koronasulun seurauksena erimielisyydet parisuhteessa lisääntyivät kansainvälisten tutkimusten mukaan yleisemmin pariskunnilla, joilla oli pieniä tai päiväkoti-ikäisiä lapsia $(44,45)$. Tämä 
sopii hyvin meidän tutkimuksemme tuloksiin, sillä kokemus erimielisyyksien ja ristiriitojen lisääntymisestä puolisoiden välillä olivat vauvaperheissä yleisempi useamman kuin yhden lapsen vanhemmilla. Myös aiempien suomalaistutkimusten mukaan suomalaisissa pikkulapsiperheissä riitely on yhteydessä lasten lukumäärään (46-48). Lapsiluvun kasvaessa myös palkatonta kotityötä on enemmän. Äidit kokevat isiä yleisemmin kotitöiden jaon olevan epätasaista ja he myös raportoivat isiä yleisemmin, että kotitöiden jakamisesta tulee puolisoiden välillä riitaa. Vauvaperheet raportoivat muuta työikäistä väestöä harvemmin erimielisyyksien ja ristiriitojen vähenemisestä mutta lisääntymisestä hyvin samansuuntaisesti (37). Vanhemmat, joilla lapset ovat olleet koronaepidemian aikana kotihoidossa vanhempien yrittäessä keskittyä etätöihin, ovat kokeneet muita vanhempia useammin stressiä, masennusoireita, lasten ahdistuneisuutta tai vanhempien välistä ärtyneisyyttä $(5,41)$.

Valtaosalla vauvaperheistä koronaepidemian ei koettu vaikuttaneen vanhempien väliseen läheisyyden tunteeseen tai erimielisyyksiin. Epidemian aikana on ehkä haluttu erityisesti varjella perheen vuorovaikutussuhteita. Perhesuhteet, yhteinen tekeminen ja perheen arkisista rutiineista kiinnipitäminen ovat olleet keskeisiä selviytymiskeinoja koronaepidemian aikana lapsiperheissä $(5,16)$. Useamman lapsen isien hieman yleisempi kokemus läheisyyden tunteen vähenemisestä voi liittyä siihen, että he kokivat puolisoiden keskinäisen ajan vähentyneen muita isiä useammin, vaikka molemmat vanhemmat kokivatkin perheen yhteisen ajan lisääntyneen. Äideillä ei ollut lapsiluvun mukaista eroa kokemuksessa läheisyyden tunteen muutoksesta. Onkin tärkeää, että parisuhteen molempien osapuolien kokemukset huomioidaan, erilaiset kokemukset tunnistetaan ja osataan tarvittaessa antaa oikeanlaista tukea.

Jaksamisen haasteet ovat yhteydessä paitsi koettuun uupumiseen ja masennukseen $(43,45)$, myös kiireiseen ja kuormittavaan työtilanteeseen (44). Vauvaperheissä äidit olivat kyselyn aikaan perhevapaalla, ja osa heistä koki jaksamisen lisääntyneen. Koronaepidemian koettu vaikutus jaksamiseen oli äideillä polarisoitunutta sekä lapsiluvun että taloudellisen tilanteen mukaan. Koronasulun vaikutusten polarisoitumista nähtiin myös espanjalaisessa tutkimuksessa, jonka mukaan sulun vaikutukset ovat lapsiperheissä monisyisiä (44). Lasten määrä voi liittyä sekä jaksamista lisääviin myönteisiin tunnekokemuksiin että suurempaan työmäärään, joka kuormittaa jaksamista $(5,44)$.

Suuremman perheen on nähty olevan suojaava tekijä eristysaikana (5) ja vähentävän yksinäisyyden kokemusta (41), mutta toisaalta juuri lisäävän vanhempien korona-ajan kuormitusta $(5,43,45)$. Työn ja yksityiselämän väliset jännitteet - kuten työstä johtuva ajan tai jaksamisen puute perheen kanssa - eivät ole koronaepidemian myötä helpottuneet pienten lasten vanhemmilla toisin kuin lapsettomilla ja koululaisten vanhemmilla (49).

Vauvaperheiden äidit kokivat isiä yleisemmin jaksamisensa vähentyneen, kuten on todettu myös kansainvälisissä tutkimuksissa $(45,50,51)$. Koronaepidemian aikana äidit ja erityisesti useamman lapsen äidit ovat kahden vanhemman lapsiperheissä olleet isiä useammin vastuussa lastenhoidosta, kotitöistä ja etäkoulua käyvien koululaisten opettamisesta, kun taas isät ovat voineet keskittyä enemmän ansiotyöhön ja nauttineet edelleen perhe-elämän hyvistä puolista (12,50-52). Toisaalta kuten meidänkin tutkimuksessamme, etätöihin jääneet isät saivat aiempaa enemmän aikaa perheelleen, mikä Marchettin ja muiden (45) laadullisen tutkimuksen mukaan on osalla, ja erityisesti useamman lapsen isillä, lisännyt tyytyväisyyttä ja muuttanut käsitystä vanhemmuudesta, positiiviseen suuntaan.

Verrattuna kaikkiin työikäisiin koronaepidemia ei heikentänyt vauvaperheiden taloudellista tilannetta yhtä yleisesti: $27 \%$ työikäisistä kertoi epidemian jonkin verran heikentäneen taloudellista tilannettaan (53). Epidemian vaikeutuessa ja pitkittyessä sen on arvioitu lisäävän väestön taloudellisia ongelmia ja niihin liittyviä huolia $(5,43,53)$. Tämä koskettanee yhtä lailla myös vauvaperheitä. Työttömyys ja lomautukset kohdentuivat perheisiin yksinasuvia voimakkaam$\min (12)$.

Lastensuojelun keskusliiton kyselyssä lähes neljäsosa lapsiperheiden vanhemmista totesi nauttineensa poikkeusajasta (3). Myös osassa vauvaperheitä hyvinvointi on koronaepidemiasta johtuvan poikkeuksellisen tilanteen vuoksi ollut tavallistakin parempaa. Näin on todettu myös muualla kuin Suomessa $(45,55)$. Kuitenkin monet jo ennestään haavoittuvammassa asemassa olevat perheet ovat kohdanneet korona-aikana 
entistä suurempia haasteita ja riskejä $(3,5,56)$. Jo prenataalivaiheen kuormitustekijöiden kuten taloudellisten ongelmien, parisuhdeongelmien, raskaana olevan äidin masennuksen sekä sosiaalisen tuen ja läheisyyden puuttumisen tai vähäisyyden tiedetään vaikuttavan vanhemmuuteen ja koko perheen dynamiikkaan (20).

Vauvaperheiden vanhempien kuormitus lisääntyy, jos palvelujärjestelmä ei pysty vastaamaan heidän tuen tarpeisiinsa. Koronaepidemian aikana syntyi paljon palveluvelkaa ja myös pikkulapsiperheiden yleisimmin käyttämien palvelujen kuten neuvola- ja lääkäripalvelujenkäyttö väheni selvästi (39), mikä heijastui myös vanhempien uupumusoireiden lisääntymiseen (57, 58). Suomalaistutkimuksen mukaan pikkulapsiperheiden vanhempien uupumuksen oireiden esiintyvyys kaksinkertaistui korona-aikana (57). Perhe- ja synnytysvalmennuksien puute, synnytyksessä mukana olevan tukihenkilön osallistumisen rajoitukset ja väliaikainen synnytyssairaalassa oloajan lyhentäminen heijastuivat vauvaperheiden hyvinvointiin (19). Epidemian alussa vallinnut epätietoisuus koronaviruksen haitallisuudesta raskauteen ja synnytykseen oli omiaan vielä lisäämään lasta odottavien perheiden huolia (32).

\section{ЈOHTOPÄÄTÖKSIÄ}

Koronaepidemia rajoittamistoimenpiteineen on vauvaperheissä lisännyt huolta, vähentänyt vanhempien oman kokemuksen mukaan heidän jaksamistaan ja sosiaalisia suhteitaan ja siten lisännyt kokemusta yksinäisyyden tunteen lisääntymisestä. Toisaalta joidenkin perheiden kokemuksen mukaan yhteinen aika ja hyvinvointi ovat lisääntyneet. Koetut vaikutukset ovat osin erilaisia äideillä ja isillä sekä yhden tai useamman lapsen perheissä. Yksinäisyyden tunteen lisääntyminen näyttää kuitenkin olevan jaettu kokemus.

Kaikilla vauvaperheillä koronaepidemia ei kuitenkaan vanhempien kokemuksen mukaan muuttanut arkea tai muutti sitä vain joiltakin osin. Tämä voi johtua osaltaan siitä, että vauvan tulo perheeseen muuttaa joka tapauksessa elämää; muutoksia voi olla vaikea erottaa toisistaan. Vauva tuo elämään sisältöä, merkitystä ja tekemistä. Vanhemmat ovat kuvanneet uusien rutiinien löytymisen helpottavan korona-arkea
(45). Erityisesti vauvaperheissä arki voi normaalioloissakin olla paljolti kotiin keskittyvää, jolloin vanhemmat eivät koe rajoittamistoimien ehkä niin paljon vaikuttaneen arkeen.

Lapsiperheiden vanhemmat kokevat saavansa apua ja tukea etenkin lapsen kasvuun ja kehitykseen liittyviin huoliin, mutta vanhemmuuteen tai perheen tilanteeseen apua saadaan huomattavasti harvemmin, osittain siksi, ettei tuen tarvetta esimerkiksi oman jaksamisen tai parisuhteen osalta ilmaista lapsi- ja perhepalvelujen ammattilaisille $(8,58)$.

Koronaepidemian aikana ja myös sen jälkeen onkin erittäin tärkeää kiinnittää huomiota sekä isien että äitien jaksamiseen, yhden ja useamman lapsen perheiden hyvinvointiin ja heille tarjottuun tukeen ja palveluihin. Koronan vaikutukset hyvinvointiin tulevat olemaan pitkäkestoisia $(5,16)$, joten korona-aikana vauvan saaneiden, vauva-arkea eläneiden ja syntyneiden vauvojen terveyttä ja hyvinvointia on tärkeä seurata jatkossakin.

Koronaepidemia on toisaalta lisännyt palvelujen tarvetta ja toisaalta erilaisten rajoitusten ja henkilöstön siirtojen vuoksi heikentänyt palvelujen saatavuutta ja mahdollisuutta vastata tuen tarpeeseen myös lapsiperheissä (59). Jatkossa tarvitaan tutkimusta koronaepidemian vaikutuksesta parisuhteisiin, lasten ja vanhempien hyvinvoinnin osatekijöistä, riskeistä ja suojaavista tekijöistä koronaepidemian jälkeisessä tilanteessa sekä perhepolitiikan keinoista tuottaa ja turvata hyvinvointia ja korjata hyvinvoinnin vajeita.

\section{RAHOITTAJAT:}

Tähän tutkimukseen saatiin rahoitusta Valtion lisätalousarviossa Covid 19 -tutkimukseen osoitetusta THL:n koordinoimasta rahoituksesta.

\section{KIRJOITTAJIEN KONTRIBUUTIOT:}

Klemetti, Vuorenmaa, Helakorpi ja Lammi-Taskula osallistuivat tutkimuksen alkuun saattamiseen ja suunnitteluun. Klemetti, Vuorenmaa, Helakorpi ja Ervasti osallistuivat aineiston keräämiseen ja Vuorenmaa ja Ervasti aineiston analysointiin. Kaikki osallistuivat artikkelin kirjoittamiseen, kommentoimiseen ja hyväksyivät artikkelin lopullisen version. Klemetti ja Lammi-Taskula vastaavat artikkelin kokonaisuudesta. 
Background: The COVID-19 pandemic has changed the everyday life. At the beginning of the pandemic little information about the risks of the virus for pregnancy or the baby was available. The aim is to analyze worries related to the pandemic as well as changes in social relations and coping of parents of babies.

Methods: The data with mothers ( $\mathrm{N}=4550)$ and fathers $(\mathrm{N}=2955)$ were obtained from the FinChildren survey to parents of 3-6-month-old babies. The data were analyzed by a gender of parents, parents' age and education, number of children and economic situation. In a logistic regression one-child parents were compared to other parents adjusting for the parents' age, education and economic situation.

Results: The response rate was $50 \%$ for mothers and $36 \%$ for fathers. More mothers than fathers, especially among one-child parents reported worries about the COVID-19 pandemic. The most usual worries were related to delivery and hospital stay during the pandemic. A large proportion of parents did not experience impacts of the pandemic on social relations or coping. Coping was polarized among mothers: some re- ported less coping $(25 \%)$ while others reported more coping $(16 \%)$. Almost half of the parents experienced increased family time while $13 \%$ of mothers and $5 \%$ of fathers reported decreased family time. It was more common among parents to report decreased rather than increased contacts with friends and grandparents. More mothers $(48 \%)$ than fathers $(21 \%)$ reported increased loneliness. Polarisation of coping and decrease in social contacts was reported more often by those with more than one child, while decreased family time was reported more often by those with one child.

Conclusions: The COVID-19 pandemic has both negative and positive effects on the wellbeing of families with babies. It is necessary to pay attention to the coping of fathers and mothers, and their support and services and to follow the well-being of families in the future.

Keywords: COVID-19 pandemic, wellbeing, baby, parent

$\begin{array}{cc}\text { Saapunut } & (15.03 .2021) \\ \text { Hyväksytty } & (19.08 .2021)\end{array}$

\section{LÄHTEET}

(1) Otonkorpi-Lehtoranta K, Salin M, Hakovirta M, ym. Gendering Boundary Work: Childcare Division Strategies among Finnish Working Parents during COVID-19 Lockdown in spring 2020. Julkaisematon artikkelikäsikirjoitus.

(2) Lammi-Taskula J, Klemetti R, Heino T, ym. Lasten, nuorten ja perheiden hyvinvointi. Kirjassa: Kestilä L, Härmä V, Rissanen P. (toim.) Covid19-epidemian vaikutukset hyvinvointiin, palvelujärjestelmään ja kansantalouteen: Asiantuntija-arvio, syksy 2020. Raportti 14/2020, Terveyden ja hyvinvoinnin laitos; 2020, 46-55. http://urn.fi/URN:ISBN:978-952-343-578-0

(3) Paju P. Paikoiltaan siirretty arki - Koronakriisin vaikutukset lapsiperheiden elämään -selvitys. Verkkojulkaisu 2/2020, Lastensuojelun Keskusliitto; 2020. https://www.lskl.fi/julkaisut/ paikoiltaan-siirretty-arki-selvitys/

(4) Willberg S, Salin M, Hakovirta M. Korona-arki ja kotityöt: ruoanlaittoa, erimielisyyksiä ja riman laskemista. YP-lehden blogi. Luettu 2.3.2021. https://blogi.yplehti.fi/korona-arki-ja-kotityotruoanlaittoa-erimielisyyksia-ja-riman-laskemista/

(5) Prime H, Wade M, Browne DT. Risk and Resilience in Family Well-Being During the COVID-19 Pandemic. Am Psychol 2020;75:631-643. http://dx.doi.org/10.1037/amp0000660

(6) Myrskylä M, Margolis R. Happiness: Before and After the Kids. Demography 2014;51:1843-1866. https://doi.org/10.1007/s13524-014-0321-x

(7) Lévesque S, Bisson V, Charton L, ym. Parenting and Relational Well-being During the Transition to Parenthood: Challenges for First-time Parents. J Child Fam Stud 2020;29:1938-1956. https://doi.org/10.1007/s10826-020-01727-z

(8) Hamelin-Brabant L, de Montigny F, Roch G, ym. Vulnérabilité périnatale et soutien social en période postnatale: une revue de la littérature. [Perinatal vulnerability and social support during the postnatal period: a review of the literature]. Santé Publique 2015;27:27-37. https://doi.org/10.3917/spub.151.0027

(9) Lindberg M. Staying Afloat: Studies on the subjective wellbeing and coping strategies of families with children in Finland. Åbo Akademi: Painosalama Oy; 2021. 
(10) Salmi M, Lammi-Taskula J. Työn ja perheen yhteensovittaminen hyvinvoinnin tekijänä. Kirjassa: Lammi-Taskula J, Karvonen S. (toim.) Lapsiperheiden hyvinvointi 2014. Tampere: Teema 21, Terveyden ja hyvinvoinnin laitos; 2014, 38-52.

(11) Halme N, Perälä M. Lapsiperheiden huolet ja avunsaanti. Kirjassa: Lammi-Taskula J, Karvonen S. (toim.) Lapsiperheiden hyvinvointi 2014. Tampere: Teema 21, Terveyden ja hyvinvoinnin laitos; 2014, 216-227.

(12) Helsinki GSE. Tilannehuoneen raportti, viimeisimmät kehityskulut työmarkkinoilla, kotitalouksissa ja yrityksissä. Luettu 2.3.2021. https://www.helsinkigse.fi/corona/ tilannehuoneen-raportti-08-10-2020viimeisimmat-kehityskulut-tyomarkkinoillakotitalouksissa-ja-yrityksissa/

(13) Pelastakaa Lapset ry. Stressi, huoli ja yksinäisyys - Koronapandemian vaikutukset lasten ja nuorten elämään. Lapsen ääni 2020: lasten näkemyksiä koronakeväästä. Luettu 2.3.2021 https://s3-eu-west-1.amazonaws.com/ pelastakaalapset/main/2020/05/22105112/ Lapsen_aani_2020_FI_web.pdf

(14) AVI tiedotteet 2020: Kuntakysely. Luettu 2.3.2021. http://www.avi.fi/web/avi/-/ kuntakysely-oppimisen-tukeen-jaoppilashuoltoon-taytyy-panostaa-myospoikkeusoloissa

(15) Alasuutari M, Karila K, Lammi-Taskula J, ym. Pienten lasten perheet ja Covid-19-pandemia: uhkia vai mahdollisuuksia? Blogikirjoitus. Luettu 2.3.2021. https://blogs.tuni.fi/childcare/ blogikirjoitus/pienten-lasten-perheet-ja-covid-19pandemia-uhkia-vai-mahdollisuuksia/

(16) Salin M, Kaittila A, Hakovirta M, ym. Family Coping Strategies During Finland's COVID-19 Lockdown. Sustainability 2020;12:9133. https://doi.org/10.3390/su12219133

(17) Shockley K, Clark M, Dodd H, ym. Work-Family Strategies During COVID-19: Examining Gender Dynamics Among Dual-Earner Couples With Young Children. J Appl Psychol 2020;106:15-28. https://doi.org/10.1037/ap10000857

(18) Hietanen-Peltola M, Vaara S, Hakulinen $\mathrm{T}$, ym. Lasten, nuorten ja perheiden peruspalvelut koronakeväänä 2020. Tuloksia kouluterveydenhuollon verkoston ja perhekeskusverkoston tiedonkeruista. Työpaperi 26/2020, Terveyden ja hyvinvoinnin laitos; 2020. http://urn.fi/URN:ISBN:978-952-343-521-6

(19) Koukkula M, Bildjuschkin K, Ikonen R, ym. Synnytyssairaaloiden toiminta COVID19-epidemian aikana Suomessa keväällä ja kesällä 2020: Kysely synnytyssairaaloille ja hoitoilmoitusrekisterin ennakkotiedot synnytysten hoitoajoista. Työpaperi 41/2020, Terveyden ja hyvinvoinnin laitos; 2020. http://urn.fi/URN:ISBN:978-952-343-595-7

(20) Korja L, Lindblom J. Dynaamiset perhesuhteet vauvaperheissä. Psykologia 2013;48:356-370.

(21) Lokken EM, Walker CL, Delaney S, ym. Clinical characteristics of 46 pregnant women with a
SARS-CoV-2 infection in Washington State. Am J Obstet Gynecol 2020;223:911.e1-911.e14. https://doi.org/10.1016/j.ajog.2020.05.031

(22) Allotey J, Stallings E, Bonet M, ym. Clinical manifestations, risk factors, and maternal and perinatal outcomes of corona-virus disease 2019 in pregnancy: living systematic review and metaanalysis. BMJ 2020;370:m3320. https://doi.org/10.1136/bmj.m3320

(23) Ahlberg M, Neovius M, Saltvedt S, ym. Association of SARS-CoV-2 Test Status and Pregnancy Outcomes. JAMA 2020;324:17821785. https://doi.org/10.1001/jama.2020.19124

(24) Sutton D, Fuchs K, D’Alton M, ym. Universal Screening for SARS-CoV-2 in Women Admitted for Delivery. N Engl J Med 2020;382:21632164.

https://doi.org/10.1097/01. aoa.0000719556.78821.15

(25) Bender WR, Srinivas S, Coutifaris P, ym. The Psychological Experience of Obstetric Patients and Health Care Workers after Implementation of Universal SARS-CoV-2 Testing. Am J Perinatol 2020;37:1271-1279. https://doi.org/10.1055/s-0040-1715505

(26) Chen L, Li Q, Zheng D, ym. Clinical Characteristics of Pregnant Women with Covid-19 in Wuhan, China. N Engl J Med 2020;382:e100. https://doi.org/10.1056/NEJMc2009226

(27) RCOG. The Royal College of Obstetricians and Gynaecologists. Coronavirus (COVID-19) infection in pregnancy. Information for healthcare professionals. 2020. Version 12: Julkaistu 14.10.2020. Luettu 20.10.2020. https:/www.rcm.org.uk/media/4383/202010-14-coronavirus-covid-19-infection-inpregnancy-v12.pdf

(28) Zambrano LD, Ellington S, Strid P, ym. Characteristics of Symptomatic Women of Reproductive Age with Laboratory-Confirmed SARS-CoV-2 Infection by Pregnancy Status United States, January 22-October 3, 2020. Centers for Disease Control and Prevention (CDC). MMWR Morb Mortal Wkly Rep 2020;69:769-775. https://doi.org/10.15585/mmwr.mm6925a1

(29) CDC. Centers for Disease Control and Prevention. Coronavirus Disease 2019 (COVID-19) Pregnancy, Breastfeeding, and Caring for Newborns-verkkosivut. 2020. Luettu 3.3.2021. https:/www.cdc.gov/ coronavirus/2019-ncov/prepare/pregnancybreastfeeding.html

(30) Ellington S, Strid P, Tong VT, ym. Characteristics of women of reproductive age with laboratoryconfirmed SARS-CoV-2 infection by pregnancy status - United States, January 22 - June 7, 2020. CDC. MMWR Morb Mortal Wkly Rep 2020;69:769-775. https://doi.org/10.15585/mmwr.mm6925a1

(31) Aktiivinen Synnytys Ry. Kannanotto: Odottajien oikeuksien huomioiminen Covid19-pandemian toisessa aallossa. 2020. Luettu 20.10.2020. 
https://aktiivinensynnytys.fi/yhdistys/kannanotot/ odottajien-oikeuksien-huomioiminen-covid19pandemian-toisessa-aallossa/

(32) Kuusiaho IL, Böök ML, Rönkä A. Enemmän huolta, vähemmän tukea: yhteisvanhemmuuden ensi askeleet esikoistaan odottavilla vanhemmilla korona-aikana. Tutkiva Hoitotyö 2021;19:2028.

(33) Fager J, Leino K. Isät vauvaperheissä - aktiivinen osallisuus kiintymyssuhteen turvaajana. Katsaus kirjallisuuteen. Opinnäytetyö. Helsinki: Metropolia Ammattikorkeakoulu; 2017.

(34) Behavioural Insights on COVID-19 -työkalu. WHO ja Erfurtin yliopisto. 2020. Luettu 15.5.2021. https://www.euro.who.int/en/healthtopics/health-emergencies/coronavirus-covid-19/ publications-and-technical-guidance/riskcommunication-and-community-engagement/ who-tool-for-behavioural-insights-on-covid-19.

(35) Tilastokeskuksen erillisaineisto, 2020. 20.4.2020-12.7.2020 väleillä elävänä syntyneiden vauvojen vanhempien lukumäärät ja ikäryhmittäiset koulutustiedot koko maassa ja alueittain aggregaattitasolla. Erillispoiminta Tilastokeskuksen ja Terveyden ja hyvinvoinnin laitoksen välisen tietopalvelusopimuksen mukaisesti.

(36) Suvisaari J, Lundqvist AM, Linnaranta O, ym. Mieliala ja epidemiatilanteeseen liittyvät huolet. Kirjassa: Kestilä L, Härmä V, Rissanen P. (toim.) Covid19-epidemian vaikutukset hyvinvointiin, palvelujärjestelmään ja kansantalouteen: Asiantuntija-arvio, syksy 2020. Raportti 14/2020, Terveyden ja hyvinvoinnin laitos; 2020, 16-21. http://urn.fi/URN:ISBN:978-952-343-578-0

(37) Lundqvist AM, Haario P, Härkänen T, ym. Arkielämä ja elintavat. Kirjassa: Kestilä L, Härmä V, Rissanen P. (toim.) Covid19-epidemian vaikutukset hyvinvointiin, palvelujärjestelmään ja kansantalouteen: Asiantuntija-arvio, syksy 2020. Raportti 14/2020, Terveyden ja hyvinvoinnin laitos; 2020, 22-28. http://urn.fi/URN:ISBN:978-952-343-578-0

(38) Parikka S, Ikonen J, Koskela T, ym. Koronan vaikutukset vaihtelevat alueittain - eroja myös ikääntyneillä sekä toimintarajoitteisilla verrattuna muuhun väestöön. Kansallisen FinSote-tutkimuksen ennakkotuloksia syksyllä 2020. Luettu 19.1.2021. http://www. terveytemme.fi/finsote/korona2020/index.html

(39) Hastrup A, Hakulinen T, Hietanen-Peltola M, ym. Lasten, nuorten ja perheiden palvelut. Kirjassa: Kestilä L, Härmä V, Rissanen P. (toim.) Covid19-epidemian vaikutukset hyvinvointiin, palvelujärjestelmään ja kansantalouteen: Asiantuntija-arvio, syksy 2020. Raportti 14/2020, Terveyden ja hyvinvoinnin laitos; 2020, 109-118. http://urn.fi/URN:ISBN:978-952-343-578-0

(40) Eurofound. Living, working and COVID-19 First findings - April 2020. Publications Office of the European Union; 2020. Luettu 5.3.2021. https://www.eurofound.europa.eu/sites/default/ files/ef_publication/field_ef_document/ef20058en. pdf
(41) Sorsa T, Rotkirch A. Työ ja perhe ne yhteen soppii? Vanhemmuuden ja työn yhteensovittaminen suomalaisissa lapsiperheissä. Perhebarometri 2020. Katsauksia E43/2020, Väestöntutkimuslaitos; 2020. https://www. vaestoliitto.fi/uploads/2020/11/4fc89cfdperhebarometri2020.pdf

(42) Kovacs B, Caplan N, Grob S, ym. Social Networks and Loneliness During the COVID-19 Pandemic. Socius 2021;7:1-16. https://doi.org/10.1177/2378023120985254

(43) Westrupp EM, Bennett C, Berkowitz T, ym. Child, parent, and family mental health and functioning in Australia during COVID-19: Comparison to pre-pandemic data. Dev Psychol Pre print 30.9.2020.

https://doi.org/10.31234/osf.io/ydrm9

(44) Günther-Bell C, Vilaregut A, Carratala E, ym. Mixed-method Study of Individual, Couple, and Parental Functioning During the State-regulated COVID-19 Lockdown in Spain. Fam Proc 2020;59:1060-1079. https://doi.org/10.1111/famp.12585

(45) Marchetti D, Fontanesi L, Mazza C, ym. Parenting-Related Exhaustion During the Italian COVID-19 Lockdown. J Ped Psychol 2020;45:1114-1123.

https://doi.org/10.1093/jpepsy/jsaa093

(46) Miettinen A. Kotityöt, sukupuoli ja tasaarvo. Palkattoman työn jakamiseen liittyvät asenteet ja käytännöt Suomessa. Väestöliitto, Väestöntutkimuslaitoksen julkaisusarja E 32 /2008. Helsinki: Yliopistopaino; 2008.

(47) Lammi-Taskula J, Salmi M. Huoli jaksamisesta vanhempana. Kirjassa: Moisio P, Karvonen S, Simpura J, Heikkilä M. (toim.) Suomalaisten hyvinvointi 2008. Sosiaali- ja terveysalan tutkimus- ja kehittämiskeskus, Stakes. Vammala: Stakes; 2008, 36-60.

(48) Lammi-Taskula J, Salmi, M. Työnjako ja tyytyväisyys parisuhteeseen lapsiperheissä. Kirjassa: Lammi-Taskula J, Karvonen S. (toim.) Lapsiperheiden hyvinvointi 2014. Tampere: Teema 21, Terveyden ja hyvinvoinnin laitos; 2014, 72-81.

(49) Schieman S, Badawy PJ, Milkie MA, ym. WorkLife Conflict During the COVID-19 Pandemic. Socius 2021;7:1-19. https://doi.org/10.1177/2378023120982856

(50) Griffith AK. Parental burnout and child maltreatment during the COVID-19 pandemic. J Fam Viol 2020;1-7. https://doi.org/10.1007/s10896-020-00172-2

(51) Spinelli M, Lionetti F, Pastore M, ym. Parents' stress and children's psychological problems in families facing the COVID-19 outbreak in Italy. Front Psychol 2020;11:1713. https://doi.org/10.3389/fpsyg.2020.01713

(52) Lahtinen J. Myös etäohjauksessa ja -opetuksessa tulee edistää tasa-arvoa ja yhdenvertaisuutta (tulossa, työnimi). Kirjoitus Potentiaali-hankkeen verkkosivuilla. Luettu 20.2.2021. www. potentiaalihanke.fi 
(53) Karvonen S, Kestilä L, Härmä V, ym.

Lomautukset, työttömyys ja koettu toimeentulo. Kirjassa: Kestilä L, Härmä V, Rissanen P. (toim.) Covid19-epidemian vaikutukset hyvinvointiin, palvelujärjestelmään ja kansantalouteen: Asiantuntija-arvio, syksy 2020. Raportti 14/2020, Terveyden ja hyvinvoinnin laitos; 2020, 38-45. http://urn.fi/URN:ISBN:978-952-343-578-0

(54) Evans S, Mikocka-Walus A, Klas A, ym. From "It Has Stopped Our Lives" to "Spending More Time Together Has Strengthened Bonds": The Varied Experiences of Australian Families During COVID-19. Front Psycho 2020;11:588667. https://doi.org/10.3389/fpsyg.2020.588667

(55) Lapset, nuoret ja koronakriisi. Lapsistrategian koronatyöryhmän arvio ja esitykset lapsen oikeuksien toteuttamiseksi. Valtioneuvoston julkaisuja 2021:2, Valtioneuvosto; 2021. http://urn.fi/URN:ISBN:978-952-383-674-7

(56) Lammi-Taskula J, Vuorenmaa M, Aunola $\mathrm{K}$, ym. Matalan kynnyksen sosiaalipalvelut lapsiperheiden tukena ja palveluiden käyttö COVID-19-epidemian aikana. Tutkimuksesta tiiviisti 15/2020, Terveyden ja hyvinvoinnin laitos; 2020. http://urn.fi/URN:ISBN:978-952-343-522-3

(57) Sorkkila M, Aunola K. Recilience and parental burnout among Finnish parents during the COVID-19-pandemic: Variable and personoriented approaches. Fam J. 2021;1-9. https://doi.org/10.1177/10664807211027307

(58) Vuorenmaa M. Pienten lasten ja heidän perheidensä hyvinvointi 2018. Tilastoraportti 10/2019, Terveyden ja hyvinvoinnin laitos; 2019. http://urn.fi/URN:NBN:fi-fe2019050214035
(59) Kestilä L, Jokela M, Härmä V, ym. (toim.): COVID-19-epidemian vaikutukset hyvinvointiin, palvelujärjestelmään ja kansantalouteen: Asiantuntija-arvio, kevät 2021. Raportti 03/2021, Terveyden ja hyvinvoinnin laitos; 2021. http://urn.fi/URN:ISBN:978-952-343-649-7

\section{Reija Klemetti}

Kansanterveystieteen dos., tutkimuspäällikkö

Terveyden ja hyvinvoinnin laitos

Tiedolla johtaminen ja vertaiskehittäminen -yksikkö

\section{MAaret VuORENMAA}

$T t T$, erikoistutkija

Terveyden ja hyvinvoinnin laitos

Tiedolla johtaminen ja vertaiskehittäminen $-y k s i k k o ̈$

\section{Eetu ERvasti}

LuK, tutkimusassistentti

Terveyden ja hyvinvoinnin laitos

Tiedolla johtaminen ja vertaiskehittäminen $-y k s i k k o ̈$

\section{SATU Helakorpi}

FT, erikoistutkija

Terveyden ja hyvinvoinnin laitos

Tiedolla johtaminen ja vertaiskehittäminen $-y k s i k k o ̈$

JoHANna LAMmi-TaSKula

YTT, tutkimuspäällikkö

Terveyden ja hyvinvoinnin laitos

Hyvinvointivaltion tutkimus ja undistaminen $-y k s i k k o ̈$ 
Liitetaulukko. Koronaepidemian aiheuttamat huolestuneisuus ja arjessa tapahtuneet koetut muutokset vauvaperheissä koulutuksen, iän ja taloudellisen tilanteen mukaan FinLapset-kyselytutkimuksessa 2020

\begin{tabular}{|c|c|c|c|c|c|c|c|c|c|c|}
\hline & \multirow[b]{2}{*}{$\begin{array}{l}\text { Perus- } \\
\text { koulu } \\
\text { tai } \\
\text { vähem- } \\
\text { män } \\
(\mathrm{n}=179)\end{array}$} & \multicolumn{3}{|c|}{ Äidit $^{1}$, koulutus } & \multicolumn{5}{|c|}{ Isät ${ }^{1}$, koulutus } & \multirow[b]{2}{*}{ P-arvo ${ }^{2}$} \\
\hline & & $\begin{array}{l}\text { Vähin- } \\
\text { tään } \\
\text { toisen } \\
\text { asteen } \\
\text { tutkinto } \\
(\mathrm{n}=1603)\end{array}$ & $\begin{array}{l}\text { AMK- tai } \\
\text { alempi } \\
\text { korkea- } \\
\text { koulutut- } \\
\text { kinto } \\
(\mathrm{n}=1549)\end{array}$ & $\begin{array}{l}\text { Ylempi } \\
\text { ammatti- tai } \\
\text { korkeakoulu- } \\
\text { tutkinto } \\
(\mathrm{n}=1201)\end{array}$ & P-arvo ${ }^{2}$ & $\begin{array}{l}\text { Perus- } \\
\text { koulu tai } \\
\text { vähem- } \\
\text { män } \\
(\mathrm{n}=161)\end{array}$ & $\begin{array}{l}\text { Vähintään } \\
\text { toisen } \\
\text { asteen } \\
\text { tutkinto } \\
(\mathrm{n}=1292)\end{array}$ & $\begin{array}{l}\text { AMK- tai } \\
\text { alempi } \\
\text { korkea- } \\
\text { koulutut- } \\
\text { kinto } \\
(\mathrm{n}=741)\end{array}$ & $\begin{array}{c}\text { Ylempi } \\
\text { ammatti- } \\
\text { tai korkea- } \\
\text { koulututkinto } \\
(\mathrm{n}=751)\end{array}$ & \\
\hline \multicolumn{11}{|l|}{$\begin{array}{l}\text { Huolestuneisuus (melko tai hyvin } \\
\text { paljon huolissaan) }\end{array}$} \\
\hline $\begin{array}{l}\text { Koronavirustartunnan saaminen } \\
\text { (itse tai perheenjäsen) }\end{array}$ & 22,4 & 31,3 & 32,1 & 34,1 & 0,018 & 22,9 & 17,0 & 21,8 & 20,2 & 0,027 \\
\hline Muiden tartuttaminen & 17,2 & 18,3 & 19,5 & 21,4 & 0,190 & 18,1 & 12,7 & 16,1 & 14,8 & 0,090 \\
\hline $\begin{array}{l}\text { Vauvan odotusajan sujuminen } \\
\text { koronaepidemian aikana }\end{array}$ & 54,8 & 60,6 & 60,4 & 59,5 & 0,490 & 39,3 & 35,7 & 39,0 & 37,3 & 0,500 \\
\hline $\begin{array}{l}\text { Synnytyksen sujuminen } \\
\text { koronaepidemian aikana }\end{array}$ & 41,8 & 44,5 & 47,1 & 46,5 & 0,340 & 27,3 & 25,7 & 30,6 & 30,0 & 0,073 \\
\hline $\begin{array}{l}\text { Synnytyssairaalassa oloaika } \\
\text { koronaepidemian aikana }\end{array}$ & 45,0 & 45,7 & 47,6 & 43,4 & 0,190 & 35,3 & 29,5 & 33,1 & 30,2 & 0,230 \\
\hline $\begin{array}{l}\text { Koronaviruksen vaarallisuus sikiölle } \\
\text { tai vauvalle }\end{array}$ & 55,4 & 59,6 & 58,8 & 59,7 & 0,710 & 34,7 & 35,8 & 38,6 & 35,9 & 0,590 \\
\hline \multicolumn{11}{|l|}{ Arjessa tapahtuneet muutokset ${ }^{4}$} \\
\hline Jaksaminen arjessa & & & & & $<0,001$ & & & & & $<0,001$ \\
\hline Lisääntynyt & 18,5 & 15,1 & 14,6 & 16,7 & & 9,0 & 8,9 & 14,4 & 16,0 & \\
\hline Vähentynyt & 13,9 & 20,5 & 25,3 & 30,7 & & 12,5 & 11,9 & 20,5 & 25,8 & \\
\hline $\begin{array}{l}\text { Puolisoiden väliset erimielisyydet ja } \\
\text { ristiriidat }\end{array}$ & & & & & 0,940 & & & & & $<0,001$ \\
\hline Lisääntyneet & 14,4 & 14,6 & 14,4 & 15,9 & & 12,9 & 9,6 & 15,7 & 13,8 & \\
\hline Vähentyneet & 2,9 & 3,5 & 3,7 & 3,8 & & 5,0 & 3,1 & 4,2 & 5,1 & \\
\hline $\begin{array}{l}\text { Puolisoiden välinen läheisyyden } \\
\text { tunne }\end{array}$ & & & & & $<0,001$ & & & & & $<0,001$ \\
\hline Lisääntynyt & 11 & 14,1 & 18,4 & 21,8 & & 13,8 & 13,7 & 18,7 & 18,4 & \\
\hline Vähentynyt & 6,2 & 6,6 & 5,9 & 7,6 & & 6,9 & 4,1 & 6,5 & 7,9 & \\
\hline Perheen kanssa vietetyn ajan määrä & & & & & $<0,001$ & & & & & $<0,001$ \\
\hline Lisääntynyt & 28,9 & 36,8 & 49 & 62,9 & & 35,3 & 34,7 & 58,5 & 66,8 & \\
\hline Vähentynyt & 13,4 & 12,3 & 13 & 12,1 & & 5,8 & 5,0 & 5,0 & 5,7 & \\
\hline Yhteydenpito isovanhempiin & & & & & $<0,001$ & & & & & $<0,001$ \\
\hline Lisääntynyt & 9,6 & 13,5 & 13,4 & 14,7 & & 17,7 & 9,1 & 15,9 & 15,9 & \\
\hline Vähentynyt & 28,8 & 40,6 & 45,5 & 51,4 & & 34,8 & 35,6 & 44,4 & 45,8 & \\
\hline Yhteydenpito ystäviin & & & & & $<0,001$ & & & & & $<0,001$ \\
\hline Lisääntynyt & 10,3 & 7,3 & 7,5 & 7,7 & & 5,5 & 4,9 & 5,5 & 5,4 & \\
\hline Vähentynyt & 43,9 & 57,2 & 65,7 & 68,0 & & 43,4 & 47,2 & 66,2 & 71,5 & \\
\hline Yksinäisyyden tunne & & & & & 0,005 & & & & & $<0,001$ \\
\hline Lisääntynyt & 36,1 & 45,9 & 47,8 & 51,0 & & 24,1 & 14,5 & 24,7 & 28,2 & \\
\hline Vähentynyt & 4,9 & 2,4 & 1,9 & 1,9 & & 1,5 & 1,7 & 1,8 & 1,6 & \\
\hline
\end{tabular}

${ }^{1}$ Kysymyskohtainen vastaajamäärä voi poiketa

${ }^{2}$ P-arvo Khiin neliötestissä

${ }^{3}$ Ristiintaulukoissa ja Khin neliötesteissä olivat mukana myös "Korkeintaan kohtalaisesti huolissaan” vastanneiden ryhmät

${ }^{4}$ Ristiintaulukossa ja Khin neliötesteissä olivat mukana myös ”Ei vaikutusta” vastanneiden ryhmät 


\begin{tabular}{|c|c|c|c|c|c|c|c|c|c|c|c|c|c|}
\hline \multicolumn{3}{|c|}{ Äidit $^{1}$, ikäryhmä } & \multicolumn{4}{|c|}{ Isät ${ }^{1}$, ikäryhmä } & \multicolumn{4}{|c|}{ Äidit ${ }^{1}$, taloudellinen tilanne } & \multicolumn{3}{|c|}{ Isät ${ }^{1}$, taloudellinen tilanne } \\
\hline Alle 30-v. & $30-35-v$. & Yli 35-v. & & Alle 30-v. & $30-35$-v. & Yli 35-v. & & Kohta- & Hyvä & & Kohta- & Hyvä & \\
\hline$(\mathrm{n}=1630)$ & $(n=1938)$ & $(\mathrm{n}=982)$ & $\mathrm{P}-\operatorname{arvo}^{2}$ & $(\mathrm{n}=681)$ & $(\mathrm{n}=1253)$ & $(\mathrm{n}=1021)$ & $\mathrm{P}-\operatorname{arvo}^{2}$ & $(\mathrm{n}=1549)$ & $(\mathrm{n}=2970)$ & $\mathrm{P}$-arvo ${ }^{2}$ & $(\mathrm{n}=947)$ & $(\mathrm{n}=1971)$ & $\mathrm{P}$-arvo ${ }^{2}$ \\
\hline 29,0 & 33,2 & 34,6 & 0,004 & 16,0 & 18,9 & 22,0 & 0,009 & 35,8 & 30,1 & $<0,001$ & 24,5 & 16,9 & $<0,001$ \\
\hline 18,8 & 20,8 & 18,5 & 0,199 & 13,2 & 13,8 & 15,8 & 0,264 & 21,8 & 18,4 & $<0,010$ & 18,4 & 12,5 & $<0,001$ \\
\hline 47,8 & 45,4 & 43,2 & 0,073 & 24,6 & 28,8 & 29,3 & 0,078 & 49,2 & 44,2 & $<0,010$ & 30,1 & 27,0 & 0,090 \\
\hline 64,5 & 59,1 & 54,1 & $<0,001$ & 37,0 & 36,9 & 37,3 & 0,976 & 62,7 & 58,6 & $<0,010$ & 39,7 & 35,9 & 0,049 \\
\hline 63,5 & 58,6 & 53,1 & $<0,001$ & 36,3 & 38,1 & 34,4 & 0,199 & 63,7 & 57,0 & $<0,001$ & 38,6 & 35,5 & 0,110 \\
\hline 48,9 & 44,5 & 43,0 & 0,006 & 29,0 & 31,4 & 31,2 & 0,520 & 49,9 & 43,6 & $<0,001$ & 35,1 & 28,9 & $<0,001$ \\
\hline & & & $<0,001$ & & & & $<0,001$ & & & $<0,001$ & & & 0,046 \\
\hline 13,9 & 15,3 & 18,4 & & 8,8 & 11,9 & 14,9 & & 18,4 & 13,9 & & 12,7 & 12,1 & \\
\hline 20,4 & 26,8 & 27,8 & & 13,7 & 19,9 & 17,8 & & 29,2 & 22,4 & & 20,3 & 16,6 & \\
\hline & & & 0,002 & & & & 0,041 & & & $<0,001$ & & & 0,036 \\
\hline 14,4 & 14,3 & 16,8 & & 9,6 & 12,7 & 14 & & 20,7 & 11,9 & & 14,8 & 11,4 & \\
\hline 3,0 & 3,2 & 5,5 & & 3,0 & 4,3 & 4,3 & & 3,3 & 3,8 & & 3,7 & 4,2 & \\
\hline & & & 0,005 & & & & $<0,001$ & & & $<0,001$ & & & 0,015 \\
\hline 16,4 & 17 & 20,5 & & 14,2 & 16,9 & 16,7 & & 16,4 & 18,1 & & 15,3 & 16,7 & \\
\hline 6,1 & 6,2 & 8,4 & & 2,0 & 6,8 & 7,3 & & 9,1 & 5,3 & & 7,8 & 5,1 & \\
\hline & & & $<0,001$ & & & & $<0,001$ & & & 0,009 & & & 0,009 \\
\hline 34,5 & 50,9 & 62,8 & & 35,6 & 50,4 & 56,5 & & 45,7 & 48,6 & & 44,9 & 51,1 & \\
\hline 15,3 & 12,2 & 8,9 & & 6,7 & 5,6 & 3,8 & & 14,6 & 11,5 & & 5,8 & 5,0 & \\
\hline & & & $<0,001$ & & & & $<0,001$ & & & 0,120 & & & 0,290 \\
\hline 13 & 14,2 & 14 & & 10,6 & 14,6 & 12,6 & & 14,2 & 13,5 & & 11,5 & 13,6 & \\
\hline 39,2 & 45,6 & 51,8 & & 31,9 & 39,2 & 47,7 & & 46,4 & 43,9 & & 41,3 & 40,2 & \\
\hline & & & $<0,001$ & & & & $<0,001$ & & & 0,180 & & & 0,260 \\
\hline 7,2 & 7,8 & 7,7 & & 4,5 & 5,2 & 5,8 & & 7,2 & 7,7 & & 5,4 & 5,2 & \\
\hline 55,5 & 65,4 & 68,1 & & 45,2 & 59,3 & 65,1 & & 64,5 & 61,6 & & 56,0 & 59,2 & \\
\hline & & & 0,380 & & & & 0,504 & & & $<0,001$ & & & $<0,001$ \\
\hline 46,4 & 49,3 & 45,9 & & 19,2 & 22,5 & 21,1 & & 53,2 & 44,7 & & 26,4 & 19,0 & \\
\hline 2,2 & 2,3 & 2,3 & & 2,0 & 1,4 & 1,8 & & 2,7 & 2,0 & & 1,8 & 1,6 & \\
\hline
\end{tabular}

